Atmos. Chem. Phys., 19, 15353-15376, 2019

https://doi.org/10.5194/acp-19-15353-2019

(C) Author(s) 2019. This work is distributed under

the Creative Commons Attribution 4.0 License.

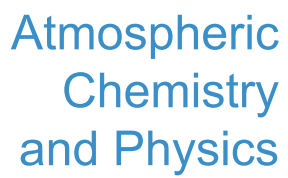

(c) (P)

\title{
Coarse and giant particles are ubiquitous in Saharan dust export regions and are radiatively significant over the Sahara
}

\author{
Claire L. Ryder ${ }^{1}$, Eleanor J. Highwood ${ }^{1}$, Adrian Walser ${ }^{2}$, Petra Seibert ${ }^{3}$, Anne Philipp ${ }^{2}$, and Bernadett Weinzierl ${ }^{2}$ \\ ${ }^{1}$ Department of Meteorology, University of Reading, Whiteknights, Reading, RG6 6BB, UK \\ ${ }^{2}$ University of Vienna, Faculty of Physics, Aerosol Physics and Environmental Physics, Vienna, Austria \\ ${ }^{3}$ University of Natural Resources and Life Sciences, Institute of Meteorology, Vienna, Austria
}

Correspondence: Claire L. Ryder (c.l.ryder@ reading.ac.uk)

Received: 1 May 2019 - Discussion started: 27 June 2019

Revised: 23 September 2019 - Accepted: 26 September 2019 - Published: 17 December 2019

\begin{abstract}
Mineral dust is an important component of the climate system, interacting with radiation, clouds, and biogeochemical systems and impacting atmospheric circulation, air quality, aviation, and solar energy generation. These impacts are sensitive to dust particle size distribution (PSD), yet models struggle or even fail to represent coarse (diameter (d) $>2.5 \mu \mathrm{m})$ and giant $(d>20 \mu \mathrm{m})$ dust particles and the evolution of the PSD with transport. Here we examine three state-of-the-art airborne observational datasets, all of which measured the full size range of dust $(d=0.1$ to $>100 \mu \mathrm{m})$ at different stages during transport with consistent instrumentation. We quantify the presence and evolution of coarse and giant particles and their contribution to optical properties using airborne observations over the Sahara (from the Fennec field campaign) and in the Saharan Air Layer (SAL) over the tropical eastern Atlantic (from the AER-D field campaign).

Observations show significantly more abundant coarse and giant dust particles over the Sahara compared to the SAL: effective diameters of up to $20 \mu \mathrm{m}$ were observed over the Sahara compared to $4 \mu \mathrm{m}$ in the SAL. Excluding giant particles over the Sahara results in significant underestimation of mass concentration (40\%), as well as underestimates of both shortwave and longwave extinction (18\% and $26 \%$, respectively, from scattering calculations), while the effects in the SAL are smaller but non-negligible. The larger impact on longwave extinction compared to shortwave implies a bias towards a radiative cooling effect in dust models, which typically exclude giant particles and underestimate coarse-mode concentrations.
\end{abstract}

A compilation of the new and published effective diameters against dust age since uplift time suggests that two regimes of dust transport exist. During the initial $1.5 \mathrm{~d}$, both coarse and giant particles are rapidly deposited. During the subsequent 1.5 to $10 \mathrm{~d}$, PSD barely changes with transport, and the coarse mode is retained to a much greater degree than expected from estimates of gravitational sedimentation alone. The reasons for this are unclear and warrant further investigation in order to improve dust transport schemes and the associated radiative effects of coarse and giant particles in models.

\section{Introduction}

Mineral dust aerosol is an important component of the climate system. Between 1000 and $4000 \mathrm{Tg} \mathrm{yr}^{-1}$ of dust is uplifted annually, with around $57 \%$ of this originating from North Africa (Huneeus et al., 2011; IPCC, 2013). Atmospheric mineral dust is estimated to account for $70 \%$ of the global aerosol mass burden and $25 \%$ of the global aerosol optical depth (AOD) (Kinne et al., 2006). During atmospheric transport and through subsequent deposition, dust exerts an impact the climate system by interacting with both shortwave and longwave radiation (Tegen and Lacis, 1996; Liao and Seinfeld, 1998). These radiative effects can impact on the global energy balance, land and sea surface temperatures, atmospheric heating, and thus circulation patterns. Impacts can be particularly strong regionally where dust loadings are high, such as the Sahara where dust affects North African atmospheric dynamics through the Saharan heat low, 
Sahelian precipitation, and North Atlantic hurricane development (e.g. Colarco et al., 2014; Pan et al., 2018; Lavaysse et al., 2011; Strong et al., 2018). Additionally, dust particles can impact cloud development by acting as cloud condensation nuclei and ice nuclei (Kumar et al., 2011; Hoose and Mohler, 2012). Dust can affect atmospheric chemistry by providing a surface for heterogeneous reactions (Bauer et al., 2004). Dust is deposited to the oceans and Amazon rainforest, providing nutrients to a variety of ecosystems (Jickells et al., 2005; Yu et al., 2015). Finally, dust is a natural hazard, having a negative impact on aviation and transport (Weinzierl et al., 2012), solar energy generation, air quality, and hence human health (Middleton et al., 2018). The annual economic cost of dust storms may reach into the billions of US dollars for certain countries (Middleton, 2017).

All of these impacts are sensitive to dust particle size (Mahowald et al., 2014). For example, dust size distribution can affect cloud interactions since smaller dust particles can be more hygroscopic (Ibrahim et al., 2018), while larger particles can be more effective cloud condensation nuclei (Petters and Kreidenweis, 2007). Size distribution also affects surface area and therefore ice nucleation (Diehl et al., 2014). Larger particles contribute more to dust mass, which controls the impact of dust on ocean and tropical rainforest ecosystems (Jickells et al., 2005; Yu et al., 2015). A higher proportion of fine particles will lead to elevated $\mathrm{PM}_{2.5}$ and subsequent impacts on respiratory health (Middleton, 2017).

Dust optical properties are influenced by several factors, including chemical composition, mixing state, particle shape, and size. Dust size distribution has a strong impact on its radiative interactions (Tegen and Lacis, 1996). In the shortwave spectrum, a larger coarse mode reduces the singlescattering albedo (SSA) of dust, causing more absorption of solar radiation and atmospheric heating. For example, Ryder et al. (2013b) found that including the coarse and giant modes over the Sahara resulted in the SSA dropping from 0.92 to 0.80 , with an associated increase in atmospheric heating by up to a factor of 3 . In the longwave spectrum, larger particles are able to exert a stronger radiative effect. For example, Otto et al. (2011) show that including particles larger than $5 \mu \mathrm{m}$ more than doubles the longwave aerosol optical depth (AOD). Together these radiative effects can change the sign of the net radiative effect of dust and the impact of dust on atmospheric circulation (Woodage and Woodward, 2014; Strong et al., 2018). Given these impacts of dust size distribution on climate and particularly radiation, it is important to have the best possible observations of dust particle size distribution (PSD) across all sizes to understand its vertical distribution through the atmosphere and how these change with transport.

Typically, dust models do not include particles larger than $20 \mu \mathrm{m}$ in diameter (Huneeus et al., 2011). Historically this has been because larger particles have been assumed to be rapidly deposited. However, recent work has shown that climate models face serious challenges in representing the dust cycle adequately, part of which stems from accurately representing dust PSDs. For example, Evan et al. (2014) find that CMIP5 climate models underestimate the dust mass path (dust mass loading per square metre) by a factor of 3 , $66 \%$ of which is due to a bias in size distribution skewed towards smaller particles. Kok et al. (2017) found that by using an observationally constrained dust emission PSD, global model calculations of dust radiative forcing were more positive $\left(-0.48\right.$ to $\left.+0.20 \mathrm{~W} \mathrm{~m}^{-2}\right)$ compared to previous estimates from AeroCom models ( -0.6 to $-0.3 \mathrm{~W} \mathrm{~m}^{-2}$ ) wherein smaller, more cooling particles were overrepresented and coarser, more warming particles were underestimated. As a result, observations of dust which include the coarse mode are in demand (Formenti et al., 2011; Ansmann et al., 2011, 2017; Samset et al., 2018) for model validation. There are also implications for satellite optical models and retrievals since these also rely on accurate aerosol optical properties, which are affected by PSD.

Airborne observations are an important tool for probing the vertical distribution of dust size and concentration. Historically, optical measurement techniques have frequently been utilized, which require a conversion of scattered signal to particle size and therefore incorporate uncertainties due to particle refractive index, shape, and non-monotonic Mie scattering (Ryder et al., 2015, 2013b; Walser et al., 2017). Many earlier measurements of dust were also limited by the maximum size measured (often not more than $10 \mu \mathrm{m}$ in diameter) or by sampling behind inlets, which restricted the maximum particle size and passing efficiency (e.g. Ryder et al., 2018 and Table 1). In the last 10 years, airborne observations of dust have progressed to measuring significantly larger particle sizes, often on wing probes which do not suffer from inlet loss effects (Weinzierl et al., 2009; Ryder et al., 2013b). More recently, light shadowing measurement techniques, which do not require a scattering to size conversion, have been applied to particles larger than $10 \mu \mathrm{m}$ in diameter (Ryder et al., 2013b, 2018). Finally, airborne observations have taken place in more remote Saharan regions where larger dust particles are more likely to be prevalent (Ryder et al., 2015; Weinzierl et al., 2009).

As a result of these developments, observational campaigns have now shown that coarse and giant dust particles are far more prevalent and transported further and higher than previously thought. Fennec, SAMUM1, SAMUM2, SALTRACE, AER-D, and ADRIMED have all reported a significant presence of coarse to giant dust particles, despite the sampling locations of Saharan dust ranging from very close to sources to thousands of kilometres away (see Table 1 for field campaign acronyms and references).

Here we contrast state-of-the art airborne observations of dust size at two stages representative of Saharan dust transport. We compare observations over the Sahara from the Fennec fieldwork to observations over the tropical eastern Atlantic within the Saharan Air Layer (SAL) from both AER$\mathrm{D}$ and Fennec fieldwork campaigns. These observations fully 


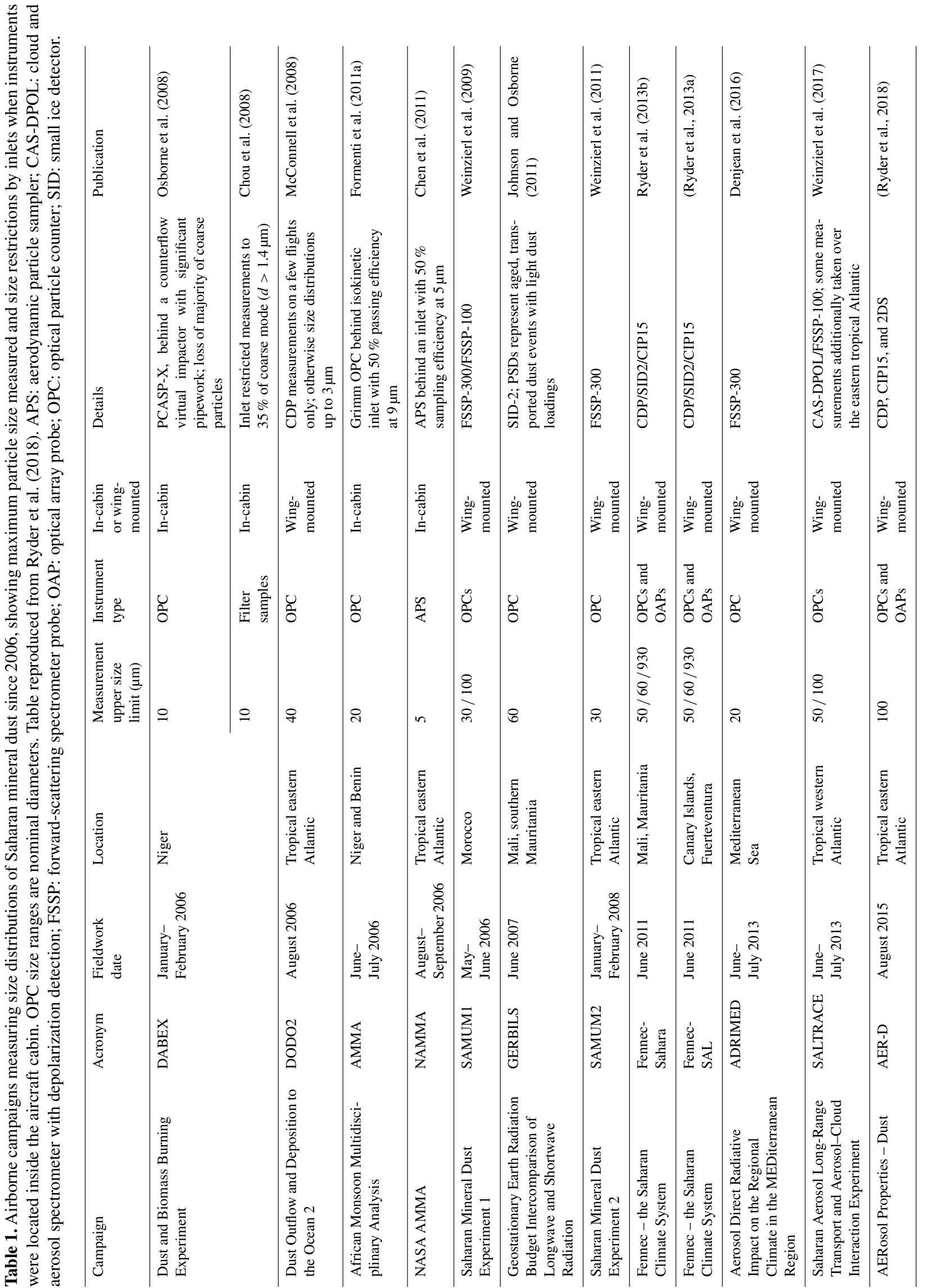


include the coarse and giant modes of dust, measuring up to $100 \mu \mathrm{m}$ for AER-D and $300 \mu \mathrm{m}$ for Fennec. Both observational campaigns use consistent instrumentation, with wing probes and light shadowing techniques for the giant mode, thus evading some of the historical measurement challenges in dust observations. The Fennec dataset is particularly novel since it includes observations within $12 \mathrm{~h}$ of dust uplift in remote Saharan locations, where few other airborne measurements (if any) have been taken.

We contrast dust characteristics close to sources with those at the beginning of trans-Atlantic transport. We present mean size distributions, vertical distributions of size metrics, and the vertical distribution of mass concentration for different size ranges, for some of which Fennec data have not previously been published. We then calculate optical properties as a function of size using the ambient number concentrations measured to illustrate the contribution of coarse and giant particles with a range of the latest refractive indices from the literature. We include longwave scattering, which is frequently neglected. Finally, we put the Fennec and AER-D size distributions and dust age into context with published airborne observations to show the wider context of the transport of coarse and giant particles.

\section{Methods}

In the literature "coarse" and "giant" aerosol particles are not well defined. This is because the origins of aerosol mode size terminology relate to broad size modes, partly overlapping in size, relating to the aerosol generation mechanism, composition, and/or measurement technique (Whitby, 1978; Kulkarni et al., 2011). For example, the lower bound of the coarse-mode diameter has been defined as particles larger than the following: $1 \mu \mathrm{m}$ (Lohmann et al., 2016; Mahowald et al., 2014), $2 \mu \mathrm{m}$ (Kulkarni et al., 2011), $2.5 \mu \mathrm{m}$ (often relating to $\mathrm{PM}_{2.5}$ ) (Neff et al., 2013; Seinfeld and Pandis, 2006; NASA, 2018), $5 \mu \mathrm{m}$ (Kok et al., 2017), and $10 \mu \mathrm{m}$ (Renard et al., 2018). Similarly, giant particles are referred to as covering a wide size range upwards of $20 \mu \mathrm{m}$ (Feingold et al., 1999), $37.5 \mu \mathrm{m}$ (Ryder et al., 2013a), $40 \mu \mathrm{m}$ (Jaenicke and Schutz, 1978), $62.5 \mu \mathrm{m}$ (Goudie and Middleton, 2001), and $75 \mu \mathrm{m}$ (Betzer et al., 1988; Stevenson et al., 2015). Weinzierl et al. (2011) do not define giant particles but start counting "large coarse-mode" dust particles upwards of $10 \mu \mathrm{m}$. Often the definitions of coarse and giant particles are relative and case study or instrument specific. In this paper we define the accumulation mode as $0.1<d<2.5 \mu \mathrm{m}$, the coarse mode as $d>2.5 \mu \mathrm{m}$, and the giant mode as $d>20 \mu \mathrm{m}$, since this is the diameter above which models rarely incorporate dust (Huneeus et al., 2011). Henceforth in this article, particle size is referred to in terms of diameter $(d)$.

\subsection{Size distribution measurement}

This work exploits airborne observations taken during the Fennec project during June 2011 over both the Sahara and in the SAL in the vicinity of the Canary Islands (Washington et al., 2012; Ryder et al., 2015), with more recent measurements over the tropical Atlantic Ocean within the SAL during the AER-D project in August 2015 (Ryder et al., 2018). Figure 1 shows the location of the fieldwork. During both fieldwork projects, the FAAM BAe146 research aircraft was deployed, and size distributions of the full particle size distribution were measured by wing probes (up to $300 \mu \mathrm{m}$ during Fennec and up to $100 \mu \mathrm{m}$ during AER-D) using a passive cavity aerosol spectrometer probe (PCASP), cloud droplet probe (CDP), and cloud-imaging probe 15 (CIP15) during Fennec and a PCASP, CDP, and 2-D stereo probe (2DS) instruments during AER-D. Size distributions from both field campaigns have already been published: full descriptions of the instrumentation, uncertainties, and findings are available for the Fennec observations over the Sahara (Fennec-Sahara: Ryder et al., 2013b), the Fennec observations in the SAL (FennecSAL: Ryder et al., 2013a), and the AER-D observations in the SAL between Cape Verde and the Canary Islands (AERD SAL: Ryder et al., 2018), as well as specific flight locations, tracks, and details of dust events sampled.

For Fennec-Sahara and AER-D-SAL, observations from horizontal flight legs are available (117 from Fennec-Sahara, 19 from AER-D-SAL), which capture some of the spatial variability in dust properties. Horizontal flight leg data are not available for Fennec-SAL, during which only take-off and landing profile observations were made. For all three campaigns observations from aircraft profiles are available (21 from Fennec-Sahara, 31 from AER-D-SAL, 21 from Fennec-SAL), which capture a more complete altitude range. Fennec-Sahara profiles do not extend all the way to the surface due to aircraft operating restrictions. In addition, both the Fennec-Sahara horizontal flight legs and profiles are separated into fresh, aged, or uncategorized dust events (see Sect. 2.3). Although each campaign lasted only around 3 weeks, the data captured by each have been shown to be climatologically representative (Ryder et al., 2015, 2018).

Besides presenting the nature of the full size distributions, we calculate two size metrics representing the full PSD. These are the maximum size detected $\left(d_{\max }\right)$ and the effective diameter $\left(d_{\text {eff }}\right)$ calculated directly from the aircraft-measured PSDs during horizontal flight legs. Effective diameter $\left(d_{\text {eff }}\right)$ is a commonly used metric (Hansen and Travis, 1974), representing an area-weighted mean diameter; $d_{\max }$ was initially used by Weinzierl et al. (2009) and is a useful indicator of the transport of the largest sizes which dominate the mass fraction. Here we use a simple estimation of $d_{\max }$ as described in Ryder et al. (2018), wherein $d_{\max }$ represents the maximum particle size during a flight leg for which at least four particles were detected within a single size bin. This implicitly represents the maximum size measured when concentrations 


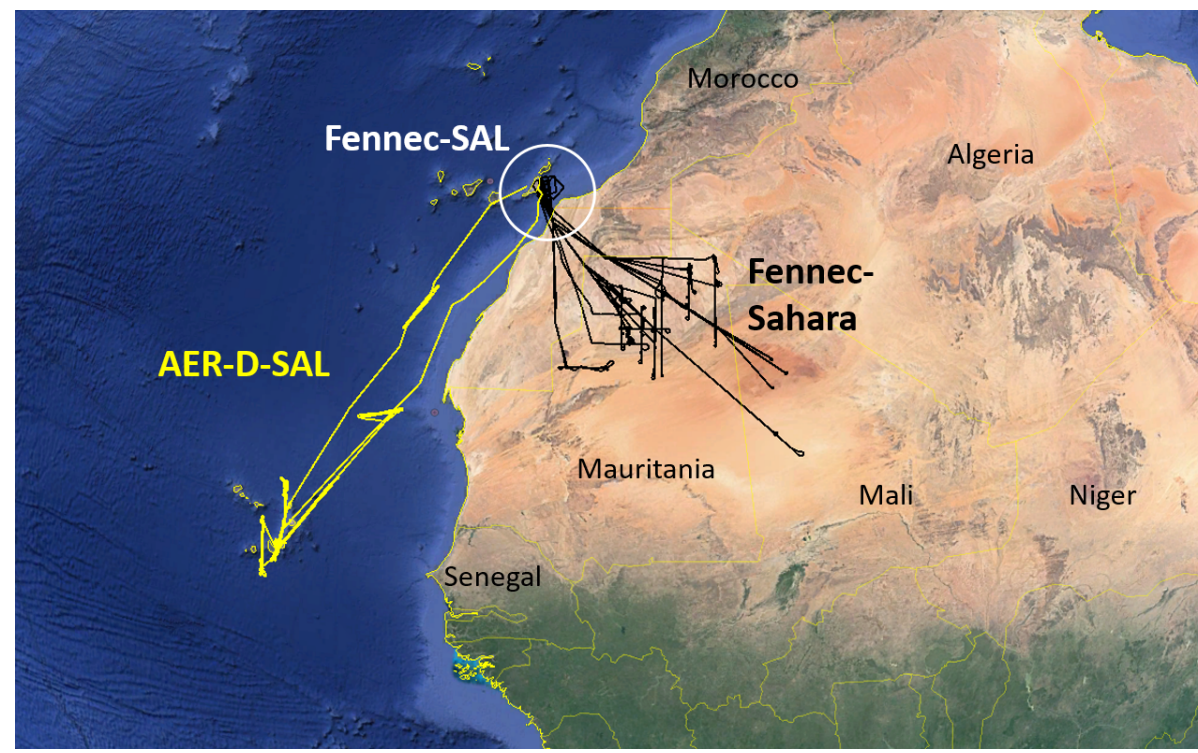

Figure 1. Map showing the locations of research flights: Fennec-Sahara in black, Fennec-SAL in black within the white circle, and AER-D SAL in yellow. Image provided using (C) Google Earth Pro. Map data: Google, SIO, NOAA, US Navy, NGA, GEBCO, Landsat/COPERNICUS.

of dust exceed $10^{-5} \mathrm{~cm}^{-3}$ (or $10 \mathrm{~m}^{-3}$ ) for a 20 min flight segment for a particle size of $30 \mu \mathrm{m}$. Full details are provided in Ryder et al. (2018). We also provide dust mass profiles calculated using the measured PSDs and assuming a density of $2.65 \mathrm{~g} \mathrm{~cm}^{-3}$ (Hess et al., 1998), which is representative of quartz particles (Woodward, 2001; Haywood et al., 2001; Kandler et al., 2009; Chen et al., 2011), taking data from aircraft profiles. Finally, we also calculate the dust mass path (DMP) as in Ryder et al. (2018): the vertically integrated mass of dust per unit surface area, which has been used in satellite and model evaluations (Evan et al., 2014). All size distributions, size metrics, and mass concentrations are provided at ambient conditions.

We provide mean size distributions for each fieldwork campaign, utilizing the lognormal size distributions (since they are easily reproducible), as well as their uncertainty ranges. For Fennec-Sahara and AER-D SAL, the lognormal PSDs are taken from horizontal flight legs representing the range of observations encountered, as shown in Fig. 2. For Fennec-Sahara, lognormal PSDs are provided in Ryder et al. (2013b). Here we use the mean log-fit curves, and as bounds of uncertainty on the PSD we also use the maximum and 10th percentile log-fit curves (orange shading in Fig. 2). The 10th percentile PSD (data given in the Supplement) is selected as the lower bound since the minimum curve for Fennec-Sahara presented in Ryder et al. (2013b) is an outlier of one case with extremely low dust loadings. For AER-D-SAL, we use the mean log-fit curve bounded by the minimum and maximum given in Ryder et al. (2018). For Fennec-SAL, only profile data are available (not horizontal flight legs). Therefore, a log-fit curve is fitted to the mean ob-

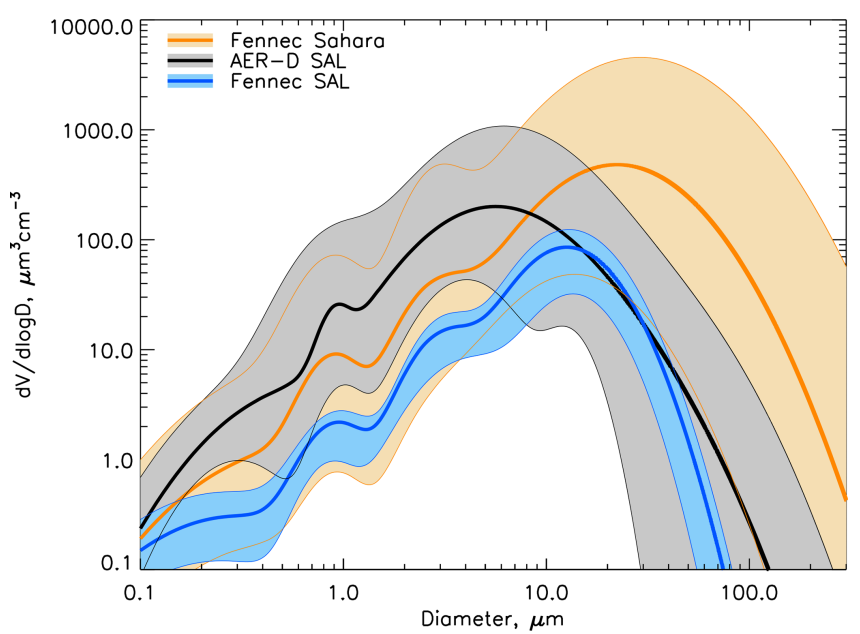

Figure 2. Campaign ambient mean log-fit size distributions for Fennec-Sahara (orange), AER-D SAL (black), and Fennec-SAL (blue). Bold lines indicate field campaign mean PSDs, and shading indicates min: max range for SAL data and 10th percentile : maximum range for Fennec-Sahara.

servational profile data from Ryder et al. (2013a) as shown by the blue line in Fig. 2 (data available in the Supplement). The spread of PSDs for Fennec-SAL (blue shading) is narrower compared to the other two PSDs because the minimum and maximum represent the standard error of the mean as given in Ryder et al. (2013a).

This article expands on the existing published work and data from Fennec and AER-D. Our emphasis is on using the combination of data in the context of transport time 
and vertical distribution. New data specifically include the Fennec-SAL lognormal mean PSD and uncertainties, vertical distributions of $d_{\max }$ for Fennec-Sahara, vertical distributions of $d_{\text {eff }}$ for Fennec-Sahara separated by fresh and aged dust events, vertical distributions of mass concentration, and DMP for Fennec-Sahara and Fennec-SAL.

\subsection{Optical property calculations}

In order to calculate dust optical properties, the Fennec and AER-D mean lognormal size distributions (Sect. 2.1) are used in combination with a range of literature refractive index (RI) data and a Mie scattering code, implying a spherical assumption. Although observations show that dust is not spherical, here we retain this simplification in order to allow for a range of fast calculations and also because many climate models assume spherical properties. In the longwave spectrum, the non-sphericity effects of dust are not significant (Yang et al., 2007). Kok et al. (2017) show that dust non-sphericity increases shortwave extinction efficiency by around $50 \%$ for coarse particles, so therefore our results represent a lower bound on the impact of the coarse mode in the solar spectrum.

Spectral RI data, for which the real part represents scattering and the imaginary part represents absorption, are taken from a range of sources. For the full spectrum, RI data are available from the OPAC database (Hess et al., 1998) based on values from d'Almeida et al. (1991) and Shettle and Fenn (1979), Volz (1973), and Balkanski et al. (2007), assuming a $1.5 \%$ hematite content, as well as the World Meteorological Organization (WMO, 1983) and Fouquart et al. (1987). For the shortwave spectrum RI data are also available from Colarco et al. (2014), and for the longwave spectrum data are available from Di Biagio et al. (2017), from which we have selected the Mauritania subset as it is representative of the middle of the range for their North Africa samples. Values are shown in Fig. 3. At $0.55 \mu \mathrm{m}$ these datasets yield real values of $1.52-1.53$ and imaginary components of 0.0015 to 0.0080 . The Balkanski et al. (2007) and Colarco et al. (2014) datasets represent significantly more recent estimates of refractive index: Balkanski et al. (2007) estimate refractive indices assuming a central $(1.5 \%)$ content of hematite when hematite is embedded in a matrix of clay, and RIs are calculated assuming a dielectric mixture. Colarco et al. (2014) combine refractive indices from Colarco et al. (2002) from Total Ozone Mapping Spectrometer satellite retrievals at ultraviolet wavelengths and Kim et al. (2011) from the AERosol Robotic NETwork (AERONET) at visible wavelengths. Both of the latter two produce significantly lower imaginary parts, 0.0015 and 0.0024 at $0.55 \mu \mathrm{m}$, respectively, widely considered to be more appropriate for accurately representing dust properties and consistent with recent observations (Rocha-Lima et al., 2018). In the longwave spectrum there is more variability between the RI datasets compared to the shortwave. We highlight the use of the much more recent and higher-spectral-resolution Di Biagio et al. (2017) dataset. The older (pre-2000) longwave datasets were limited in applicability due to the fact that (1) they were collected at limited geographic locations, (2) they are based on unknown mineral composition, (3) they may have been subject to unknown physiochemical ageing, and (4) only Fouquart et al. (1987) satisfy the Kramers-Kronig relationship (Di Biagio et al., 2017).

In order to illustrate the impact of coarse particles on dust optical properties, we firstly calculate optical properties for the three mean PSDs and their uncertainties, which are calculated from the shaded PSD range shown in Fig. 2 for each campaign and which represent the variability in the PSD, as well as each of the refractive index datasets described above. Secondly, optical properties are calculated with a gradually incrementing maximum cut-off diameter for each PSD in order to show how the optical properties depend on the maximum size considered and how this differs for the three different PSDs measured during Fennec and AER-D. This enables the contribution of coarse and giant particles to the optical properties to be quantified. For these calculations only two wavelengths are selected, 0.55 and $10.8 \mu \mathrm{m}: 0.55 \mu \mathrm{m}$ since it represents the peak intensity of the solar radiation spectrum and $10.8 \mu \mathrm{m}$ since extinction from dust at this wavelength is typically quite high, it falls within the atmospheric window in which dust is able to exert a strong radiative effect, it avoids ozone and water vapour absorption channels, and it is also representative of one of the Spinning Enhanced Visible and Infrared Imager (SEVIRI) dust red-green-blue (RGB) channels (Brindley et al., 2012). Different thermal infrared wavelengths were also tested, and sensitivity to chosen wavelength in the results in Sect. 3.2.2 was found to be low.

\subsection{Estimation of dust age}

Estimates of dust age for Fennec-Sahara and AER-D since uplift are taken from Ryder et al. (2013b) and Ryder et al. (2018), respectively. Briefly, for both campaigns, broad geographic dust source locations have been identified using the SEVIRI dust RGB thermal infrared satellite imagery product (Lensky and Rosenfeld, 2008). Dust events sampled by the aircraft are tracked backwards in time visually, which allows for the determination of dust uplift time and location and therefore dust age. For Fennec, this technique was combined with back-trajectory analysis from the Hybrid Single-Particle Lagrangian Integrated Trajectory model (HYSPLIT) (Draxler and Hess, 1998) and from the FLEXible PARTicle dispersion model (FLEXPART) (Stohl et al., 2005). For AER-D, every dust event sampled could be linked to a haboob originating from a mesoscale convective system. For AER-D, only SEVIRI imagery was used for dust source identification since for each case HYSPLIT back trajectories indicated different dust source locations, likely due to poor meteorological representation over the Sahara when convection was important (Ryder et al., 2018). Dust ages for 


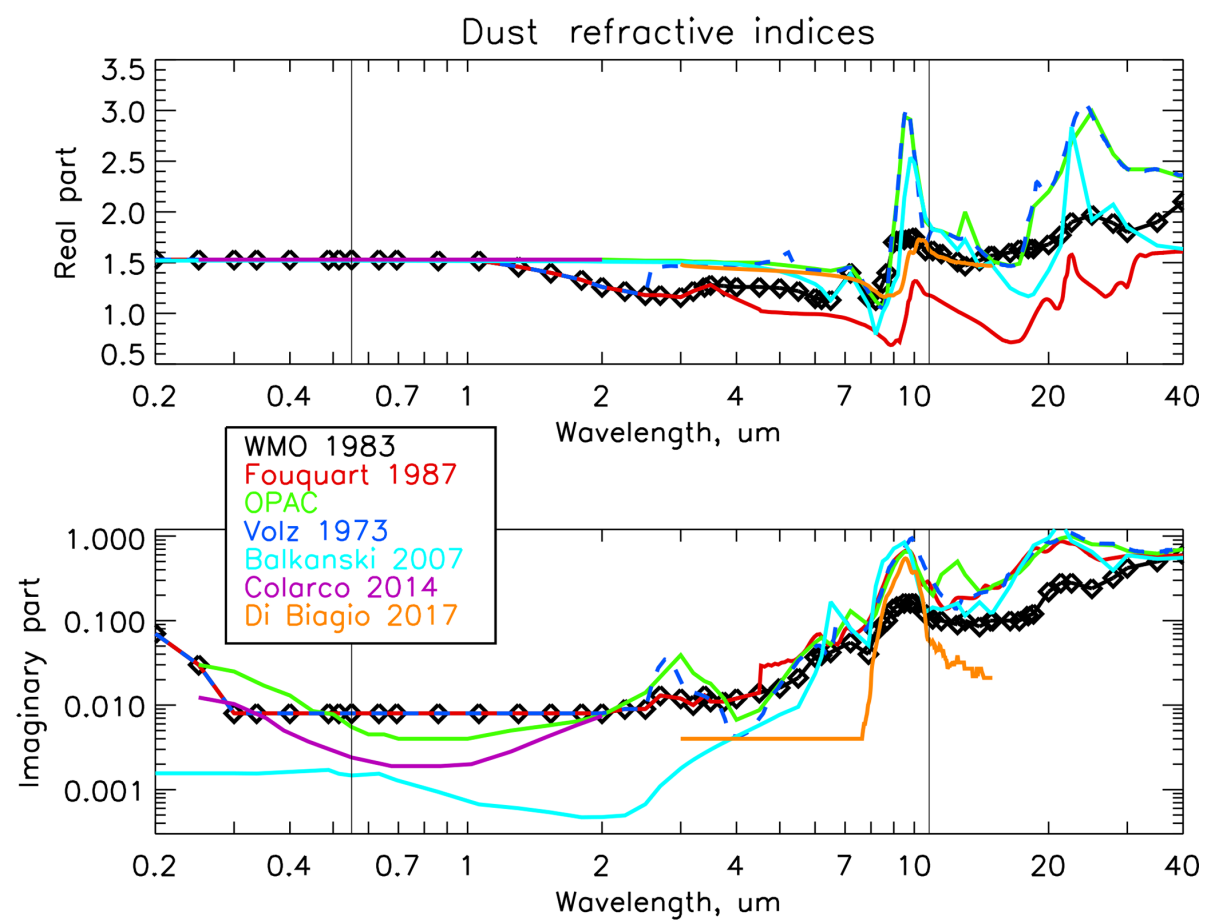

Figure 3. Dust spectral refractive index datasets from the literature. Vertical lines indicate wavelengths of 0.55 and $10.8 \mu \mathrm{m}$. See the text for dataset descriptions. Partial lines only provide a subset of spectral refractive indices.

Fennec-SAL are not included here since their values have been found to cover an extremely large range of times (Ryder et al., 2013a).

As in Ryder et al. (2013a, b), Fennec-Sahara data are also separated into "fresh" and "aged" categories, wherein fresh represents dust sampled in under $12 \mathrm{~h}$ since uplift time. Of the 119 sampling legs performed, 22 were fresh, 55 aged, and the remainder uncategorized. Of the 21 Fennec-Sahara profiles, 5 were fresh and 16 aged.

The ages of two SALTRACE dust samples from Weinzierl et al. (2017) measured over the western and eastern Atlantic were derived from new backward simulations with the Lagrangian particle dispersion model FLEXPART (Stohl et al., 1998, 2005; Seibert and Frank, 2004) using meteorological fields from the European Centre for Medium-Range Weather Forecasts ERA5 reanalysis $\left(0.25^{\circ}, 1 \mathrm{~h}\right.$ resolution $)$ as input. A generic aerosol species with a mean mass diameter of $7.9 \mu \mathrm{m}$ and logarithmic standard deviation of 2.5 was tracked back from the five selected flight segments in each location, including the effects of gravitational settling and dry and wet deposition. The model produced source-receptor sensitivity values for a $50 \mathrm{~m}$ layer adjacent to the ground. These sensitivities were multiplied with gridded, time-dependent dust emissions from the Copernicus Atmosphere Monitoring Service global natural emissions dataset to obtain the corresponding contribution to the mass. The sum of the contributions over all grid cells at each of the time steps produced is thus the simulated age distribution of the sampled dust aerosol. For both the eastern and western observations, the flight legs have been separated into five segments and the ages calculated separately for each. The best estimate of the SALTRACE dust age is given by the median for the segment with the highest receptor mass concentration, while the uncertainties are given by the minimum and maximum 25 th and 75th percentile ages across all five segments.

\section{Results}

\subsection{Size distributions, mass concentration, and vertical distribution}

The mean log-fit volume size distributions from Fennec and AER-D and their variability are shown in Fig. 2. Overall, Fig. 2 shows the following features, which will be important later in terms of optical properties: a strong giant mode for Fennec-Sahara and subsequent loss of this by Fennec-SAL and AER-D SAL; an enhanced accumulation and coarse mode for AER-D SAL relative to Fennec-Sahara and Fennec-SAL.

As expected, over the Sahara the giant mode $(d>20 \mu \mathrm{m})$ is enhanced compared to the SAL. The Fennec-Sahara PSD peaks at 20-30 $\mu \mathrm{m}$, while the AER-D-SAL PSD peaks at $5 \mu \mathrm{m}$, and the Fennec-SAL PSD peaks at 10-12 $\mu \mathrm{m}$. In these cases, this can be explained by a greater dust age and distance from dust sources contributing to the loss of the giant mode. 

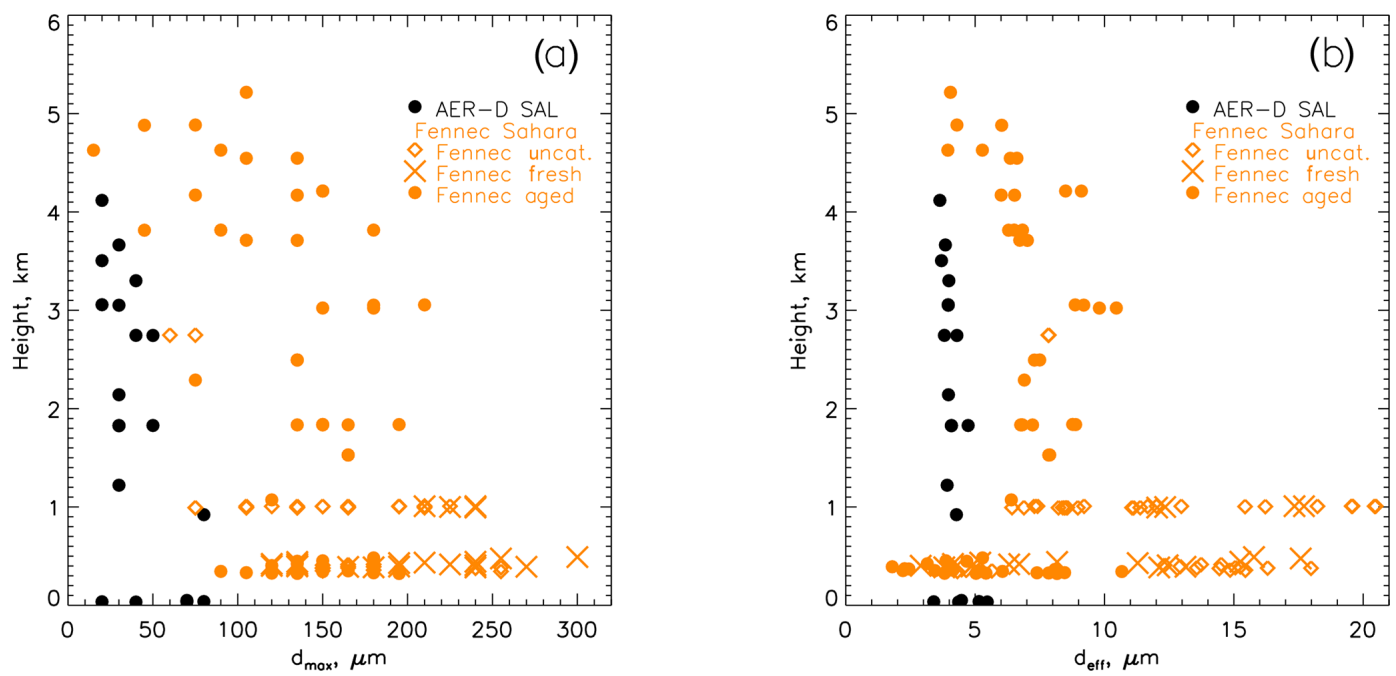

Figure 4. Variation of dust size with altitude from Fennec-Sahara and AER-D-SAL, showing (a) maximum size detected $\left(d_{\text {max }}\right)$ and (b) effective diameter $\left(d_{\text {eff }}\right)$. The $d_{\text {eff }}$ uncertainties are $5 \%$, and the $d_{\max }$ uncertainties are $10 \mu \mathrm{m}$ for AER-D and $15 \mu \mathrm{m}$ for Fennec. Data are from horizontal flight legs (and therefore not available for Fennec-SAL).

The accumulation and coarse mode are enhanced in AERD-SAL compared to Fennec-Sahara and Fennec-SAL, with higher concentrations below $10 \mu \mathrm{m}$. However, we did not observe this enhancement when the same dust events were observed in Fennec-Sahara and Fennec-SAL; rather, the accumulation and coarse modes decreased in concentration from Fennec-Sahara to Fennec-SAL. The AER-D-SAL accumulation- and coarse-mode enhancement may occur because AER-D simply sampled more intense dust events, though this seems unlikely given that the Fennec dust events were also often very intense and AODs were mostly higher than AER-D (Ryder et al., 2015). This enhancement of the accumulation mode is similar to differences between SAMUM1 (Morocco) and SAMUM2 (Cape Verde region), for which enhancements in number concentration between 0.3 and $4 \mu \mathrm{m}$ during SAMUM2 were attributed to coagulational growth (Weinzierl et al., 2011). A number of the AER-D data segments were collected further south, closer to the intertropical convergence zone in moister conditions. Therefore, another possibility is that hygroscopic growth took place, although generally dust is considered unlikely to react hygroscopically in this way (Denjean et al., 2015). Satellite imagery indicated that clouds developed in the vicinity of every dust event sampled during AER-D-SAL during transport over the Sahara. Therefore, there is a possibility that the dust was affected by cloud or water vapour recycling during its transport journey, which may have allowed for some form of coagulation, potentially impacting the size distribution (Ryder et al., 2015; Diaz-Hernandez and Sanchez-Navas, 2016; Weinzierl et al., 2011). Another possibility is that a slight difference in the dust sources activated between Fennec and AER-D led to different size distributions being mobilized initially.
Figure 4 demonstrates how dust size for Fennec-Sahara and AER-D-SAL changes with altitude $(z)$ over the desert and in the SAL. AER-D data points at $z<100 \mathrm{~m}$ are marine boundary layer samples and are not discussed. Both $d_{\text {eff }}$ and $d_{\max }$ show much larger values at all altitudes in Fennec-Sahara compared to AER-D-SAL. Over the Sahara $d_{\text {eff }}$ and $d_{\max }$ drop off sharply with altitude, while in the SAL they are more homogeneous in altitude. For Fennec-Sahara $d_{\max }$ varied from 90 to $300 \mu \mathrm{m}$ beneath $600 \mathrm{~m}$, while above $3.5 \mathrm{~km} d_{\max }$ varied from 15 to $180 \mu \mathrm{m}$. Contrastingly, values for AER-D-SAL were 20 to $80 \mu \mathrm{m}$. Particles sized over $20 \mu \mathrm{m}(100 \mu \mathrm{m})$ were detected in $99 \%(89 \%)$ of the FennecSahara dust layers, while particles sized over $20 \mu \mathrm{m}$ were always present during AER-D-SAL, though particles as large as $100 \mu \mathrm{m}$ were never detected. The impact of decreasing size with increased transport can also be seen in Fig. 4b; AER-

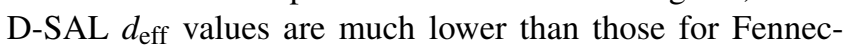
Sahara, with a range of 3.6 to $4.0 \mu \mathrm{m}$ in the SAL compared to 1.8 to $20.5 \mu \mathrm{m}$ over the Sahara.

The largest $d_{\text {eff }}$ and $d_{\max }$ values in Fig. 4 are clearly dominated by fresh dust events (under $12 \mathrm{~h}$ since uplift). However, even for aged dust events (over $12 \mathrm{~h}$ since uplift, circles) very large particles were encountered, including at high altitudes: for Fennec-Sahara aged dust $d_{\max }$ reached $195 \mu \mathrm{m}$ beneath $1.5 \mathrm{~km}$ and $210 \mu \mathrm{m}$ above $1.5 \mathrm{~km}$, while $d_{\text {eff }}$ reached $10.7 \mu \mathrm{m}$ beneath $1.5 \mathrm{~km}$ and $10.5 \mu \mathrm{m}$ above $1.5 \mathrm{~km}$. Aged $d_{\text {eff }}$ values over the Sahara are fairly homogeneous in the vertical. These large values at high altitudes indicate that the coarse and giant dust particles are entrained and transported in the atmosphere on longer than superficial timescales and that for very fresh dust the coarse and giant mode are particularly enhanced at low altitudes. 
Weinzierl et al. (2011) performed a similar comparison of $d_{\max }$ between SAMUM1 and SAMUM2. Their results are not directly comparable to ours due to different instrumentation. However, relative altitude dependencies and changes during transport can still be compared. During SAMUM1, dust was well mixed vertically, showing no altitude dependence of size and being similar to that of the aged dust from Fennec. Weinzierl et al. (2011) also saw a decrease in $d_{\max }$ between dust closer to sources in SAMUM1 (90\% of cases had particles larger than $20 \mu \mathrm{m}$ ) and low-altitude wintertime dust sampled over the Atlantic in SAMUM2 (33\% of cases had particles larger than $20 \mu \mathrm{m}$ ), similar to the $d_{\max }$ decreases between Fennec-Sahara and AER-D-SAL.

Figure 5 shows the vertically resolved mass concentrations, since they are frequently used as a model diagnostic and biogeochemical cycles and respiratory health are also impacted by dust mass. Total mass concentrations (panel a) were notably higher at all altitudes during Fennec-Sahara, gradually decreasing with altitude. In the SAL, mass concentrations were lower, peaked between 2 and $4 \mathrm{~km}$ for AER$\mathrm{D}$, and were extremely homogeneous in height for FennecSAL upwards of $1 \mathrm{~km}$. Fennec-Sahara mass concentrations can be extremely high, especially at lower altitudes, with the 75 th percentile reaching values of up to $1940 \mu \mathrm{g} \mathrm{m}^{-3}$. Contrastingly, the mass concentration in the accumulation mode (panel b) is highest during AER-D-SAL, which is a reflection of the enhanced accumulation mode shown in Fig. 2. For Fennec-Sahara, there is a sharp increase in the accumulationmode mass concentration beneath $1.4 \mathrm{~km}$. Above $1.5 \mathrm{~km}$, Fennec-SAL displays a similar profile to Fennec-Sahara, albeit in lower concentrations in keeping with the reduced concentrations shown in Fig. 2. Given that the World Health Organization limits for air quality particulate matter for $24 \mathrm{~h}$ mean $\mathrm{PM}_{2.5}$ and $\mathrm{PM}_{10}$ are 25 and $50 \mu \mathrm{g} \mathrm{m}^{-3}$, respectively, the observations in Fig. 5 are often well above these values, reinforcing the hazardous nature of dust events.

In Fig. 5c and $d$ the fraction of mass found at sizes greater than 5 and $20 \mu \mathrm{m}$ in diameter is shown. As in Ryder et al. (2018) these sizes are selected since they represent the diameters at which models begin to underestimate the concentration of coarse particles $(5 \mu \mathrm{m})$ and at which models have an upper limit $(20 \mu \mathrm{m})$ (Kok et al., 2017). It is clear in panel c that during Fennec-Sahara the vast majority of dust mass was present at sizes greater than $5 \mu \mathrm{m}$ (an average of $93 \%$ beneath $4.5 \mathrm{~km}$ ), similar to Fennec-SAL ( $89 \%$ between 1 and $5 \mathrm{~km})$, and there is also a large amount during AER-D-SAL (61\% between 1 and $4 \mathrm{~km}$ in the SAL). Since models begin to underestimate dust concentration at sizes above $5 \mu \mathrm{m}$ in diameter, showing an underestimation by up to a factor of 10 (Kok et al., 2017), a very large fraction of mass will be neglected. Similarly, during Fennec-Sahara, sizes greater than $20 \mu \mathrm{m}$ in diameter were still found to contain $40 \%$ of the dust mass beneath $4.5 \mathrm{~km}$ (panel d) or up to $68 \%$ for the 75 th percentile. For AER-D-SAL and Fennec-SAL, $2 \%$ and $12 \%$ of total mass, respectively, was found at these large diame- ters, though the 75 th percentile reaches up to $19 \%$ and $56 \%$, respectively. Since $20 \mu \mathrm{m}$ is typically the maximum diameter represented by dust models, a large fraction of dust mass over the Sahara is being completely excluded from models, and although the percentage of mass found at sizes larger than $20 \mu \mathrm{m}$ is fairly small on average, individual event values can reach much higher values, which will also be excluded by most models.

Mean DMPs are calculated at $3.2 \mathrm{~g} \mathrm{~m}^{-2}(0.8$ to $\left.12.1 \mathrm{~g} \mathrm{~m}^{-2}\right)$ for Fennec-Sahara, $1.5 \mathrm{~g} \mathrm{~m}^{-2}\left(0.2\right.$ to $\left.6.2 \mathrm{~g} \mathrm{~m}^{-2}\right)$ for AER-D-SAL, and $1.4 \mathrm{~g} \mathrm{~m}^{-2}\left(0.2\right.$ to $\left.2.3 \mathrm{~g} \mathrm{~m}^{-2}\right)$ for Fennec-SAL. As expected, mean values over the Sahara are higher compared to the SAL. All these values are much higher than those produced by models, such as the CMIP5 models analysed by Evan et al. (2014) with values of 0.05 to $0.46 \mathrm{~g} \mathrm{~m}^{-2}$ and a multi-model median of $0.26 \mathrm{~g} \mathrm{~m}^{-2}$ in the geographic region of the AER-D-SAL observations. Although the aircraft data only represent periods of around 3 weeks for each campaign, aerosol optical depths (AODs) were found to be climatological (Ryder et al., 2013b, 2018), though they do represent the dustier summer months, while the satellite and model data referred to here are annual means. An unpublished analysis of summertime-only DMPs from a subset of CMIP5 models suggests values higher by around $35 \%$ (personal communication, A. Evan, 2019) - not nearly enough to reconcile the observational-model differences.

\section{Optical properties}

\subsection{Spectral optical properties}

Figure 6a shows the spectral extinction coefficient calculated from the campaign mean full PSDs shown in Fig. 2 and the range of refractive index datasets described in Sect. 2.2. For clarity only Fennec-Sahara and AER-D-SAL are shown. In the shortwave spectrum, it is clear that the size distribution difference between Fennec-Sahara and AER-D-SAL dominates the impact on extinction, with the AER-D-SAL PSD resulting in higher extinction due to the greater number concentration between 0.5 and $8 \mu \mathrm{m}$ in diameter in AER-D-SAL compared to Fennec-Sahara. As a result, Fennec-Sahara extinction is a factor of 0.7 less than AER-D-SAL (panel b). The extinction at these wavelengths is dominated by scattering (as opposed to absorption). As the RI real parts (relevant for scattering) are similar in all cases (even though the imaginary part varies) this causes little difference to the total extinction, and therefore the size distribution is the dominant influence on extinction.

However, in the longwave spectrum, both PSD and RI are important for extinction. Different combinations of RI and PSD can give different spectral variations in extinction. Overall, the Fennec-Sahara PSD produces a higher extinction by up to a maximum factor of 3.3 for the Di Biagio RI dataset. 

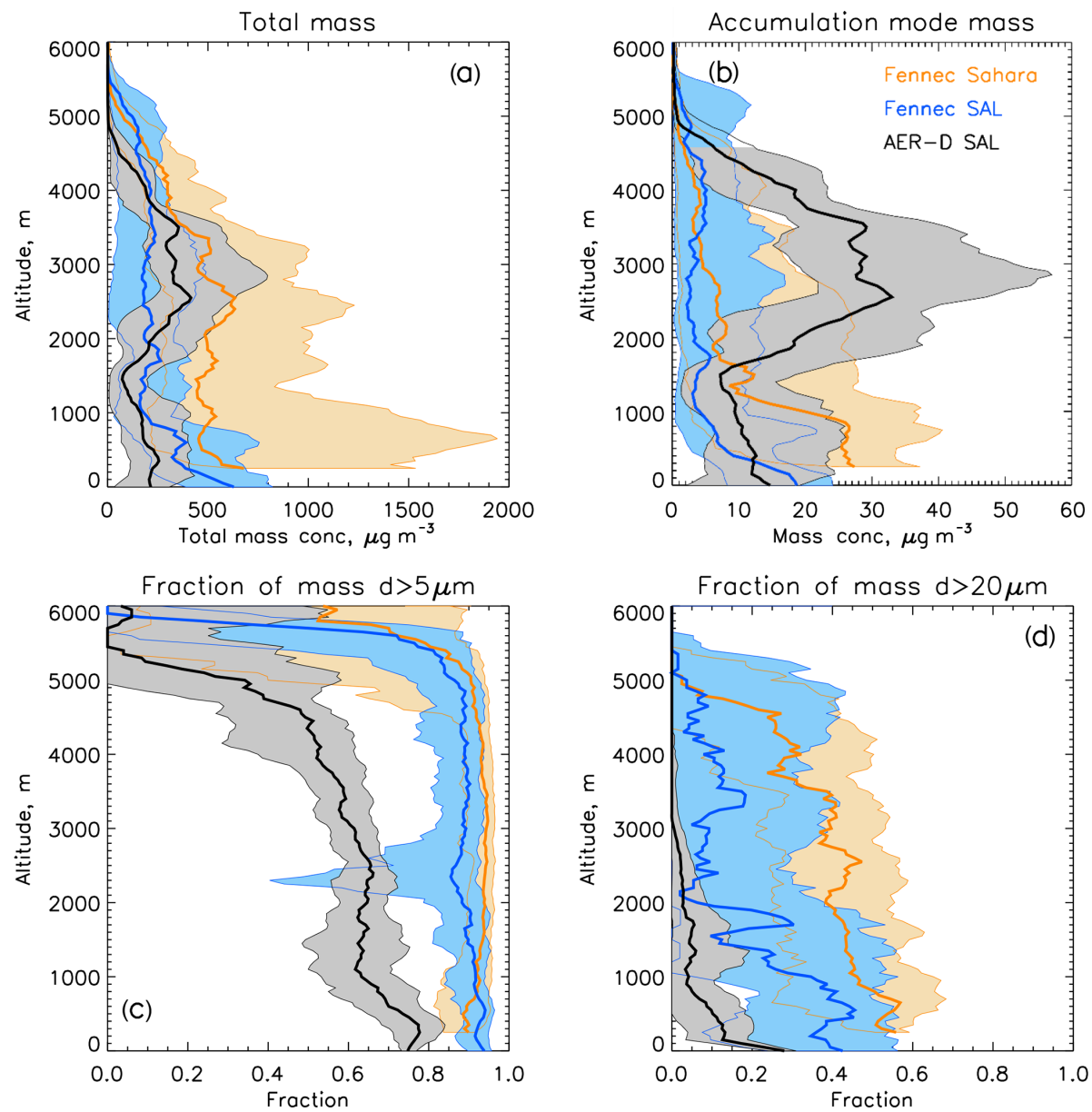

Figure 5. Vertically resolved mass concentrations for Fennec-Sahara (orange), Fennec-SAL (blue), and AER-D-SAL. (black) (a) Total mass concentration across all sizes measured; (b) accumulation-mode mass concentration $d<2.5 \mu \mathrm{m}$; (c) and (d) fraction of mass at $d>5 \mu \mathrm{m}$ (c) and $d>20 \mu \mathrm{m}$ (d). Bold lines and shading indicate the median and interquartile range, respectively. Data are smoothed over $250 \mathrm{~m}$ intervals and for Fennec-Sahara are only available down to $350 \mathrm{~m}$ due to flight restrictions.

This is due to the increased scattering and absorption from the larger particles in the Fennec-Sahara PSD. Interestingly, the application of the Fennec-Sahara PSD rather than the AER-D-SAL PSD is to dampen the spectral variability of extinction in the 7 to $12 \mu \mathrm{m}$ spectral region: exactly the region utilized by satellite retrievals to detect dust. Thus, similar to Banks et al. (2018), we find that the coarsest dust may pose a challenge to longwave satellite detection algorithms by allowing coarse dust to effectively "hide".

Figure $6 \mathrm{c}$ shows the spectral absorption coefficient for the mean PSDs and each RI dataset. Across the shortwave spectrum in general there is an increase in absorption for FennecSahara compared to AER-D-SAL, by up to a factor of 2 at a wavelength of $2 \mu \mathrm{m}$. This also shows that in the shortwave, both RI and PSD impact the spectral SSA. In the longwave spectrum, the sensitivity of absorption to variation in both PSD and RI is similar to that seen for extinction: both are important. The overall question of the relative contribution of PSD and RI uncertainty to optical property uncertainty is a complex one and depends on the optical property in question and the spectral range under consideration.

\subsection{Size-resolved optical properties}

So far, we have shown how the different PSDs contribute to different spectral extinction properties. Next, we examine the size-resolved contribution to the extinction coefficient at specific wavelengths $(0.55$ and $10.8 \mu \mathrm{m})$ in order to see how important the inclusion of a specific size range is to the optical properties.

Figure 7 shows the shortwave size-resolved percentage contribution to absorption (lightweight lines) and extinction (bold lines) coefficients at $0.55 \mu \mathrm{m}$ for three different PSDs (different colours). In each case, the campaign mean PSD (as shown in Fig. 2) and Colarco RI are used, as they represent central values. This is shown both as a percentage contribution to the total extinction (panel a) and cumulatively (panels $\mathrm{b}$ and c) to illustrate the cut-off diameter at which the major- 

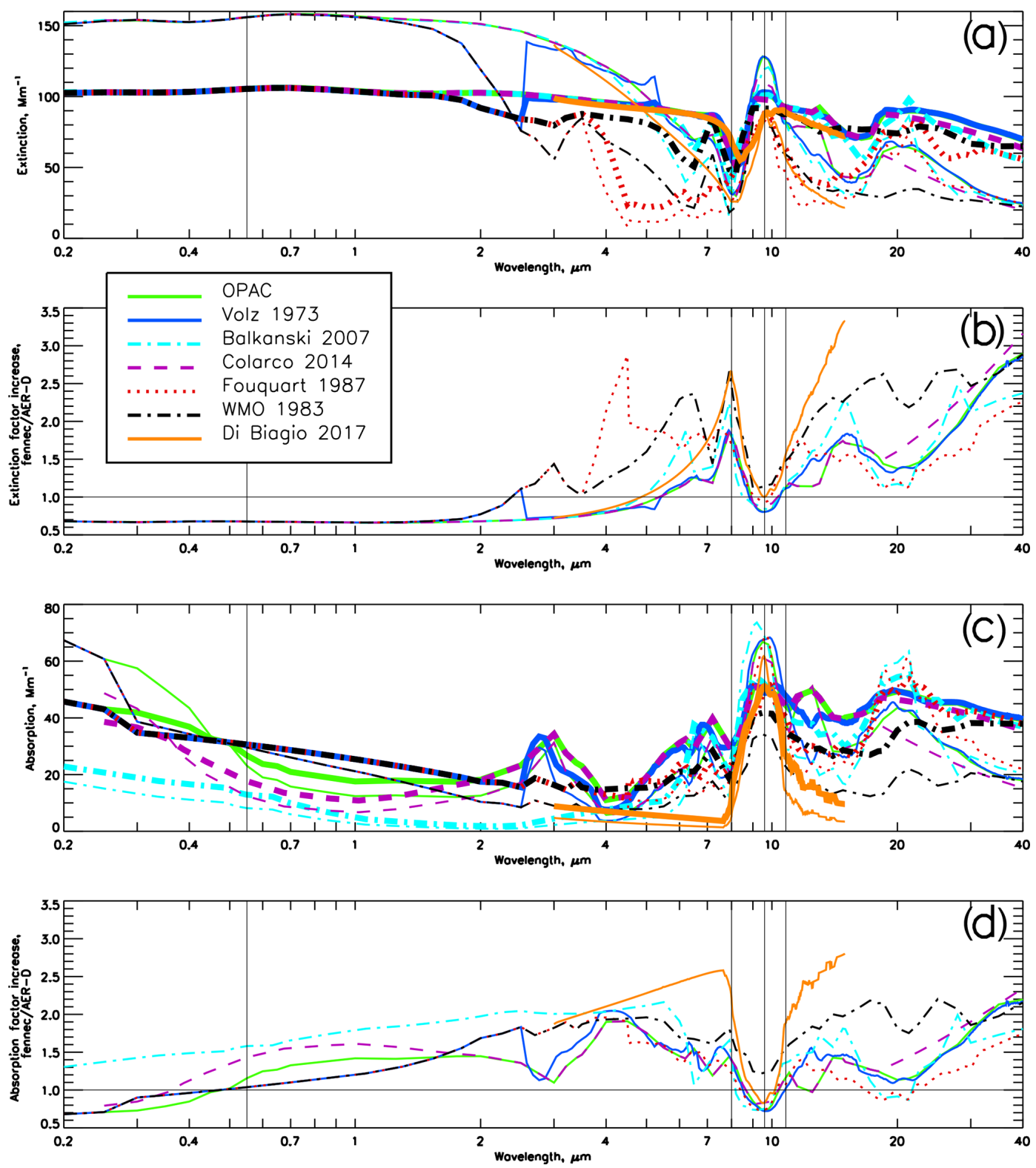

Figure 6. Calculated spectral extinction coefficient $\left(\mathrm{Mm}^{-1}\right)$ (a) and factor increase in extinction (b) between Fennec-Sahara (bold lines) and AER-D-SAL (lightweight lines), calculated spectral absorption coefficient $\left(\mathrm{Mm}^{-1}\right)$ (c), and factor increase in absorption (d) between Fennec-Sahara (bold lines) and AER-D-SAL (lightweight lines). Different colours indicate different RI datasets as in the legend. Vertical lines indicate $0.55,8.0,9.6$, and $10.8 \mu \mathrm{m}$ wavelengths.

ity of the extinction is captured. Panel a uses the Colarco RI exclusively, while in panels $\mathrm{b}$ and $\mathrm{c}$ the shading represents the uncertainty for both the ranges of PSD shown in Fig. 2 and the range of refractive indices tested.

For AER-D-SAL, Fig. 7a shows that the main extinction contribution (thick black line) comes from particles sized around 1 and $3 \mu \mathrm{m}$. The scattering percentage contribution is not shown because it is very similar to the extinction curve since the extinction is dominated by scattering. However, the absorption (thin black line) is dominated by a contribution from larger particles, with most absorption coming from particles sized around $5 \mu \mathrm{m}$. The Fennec-Sahara PSD (orange lines) shows an influence of much larger particles. In addition to the peaks at 0.9 and $3 \mu \mathrm{m}$, the largest extinction comes from $14 \mu \mathrm{m}$ diameter particles. Similarly for absorption (thin orange line), the Fennec-Sahara optical properties are strongly dominated by the giant mode, with a peak contribution from $20 \mu \mathrm{m}$ diameter particles. The properties of the Fennec-SAL dataset are between the other two datasets, with peak contributions to extinction at the $10 \mu \mathrm{m}$ diameter and 

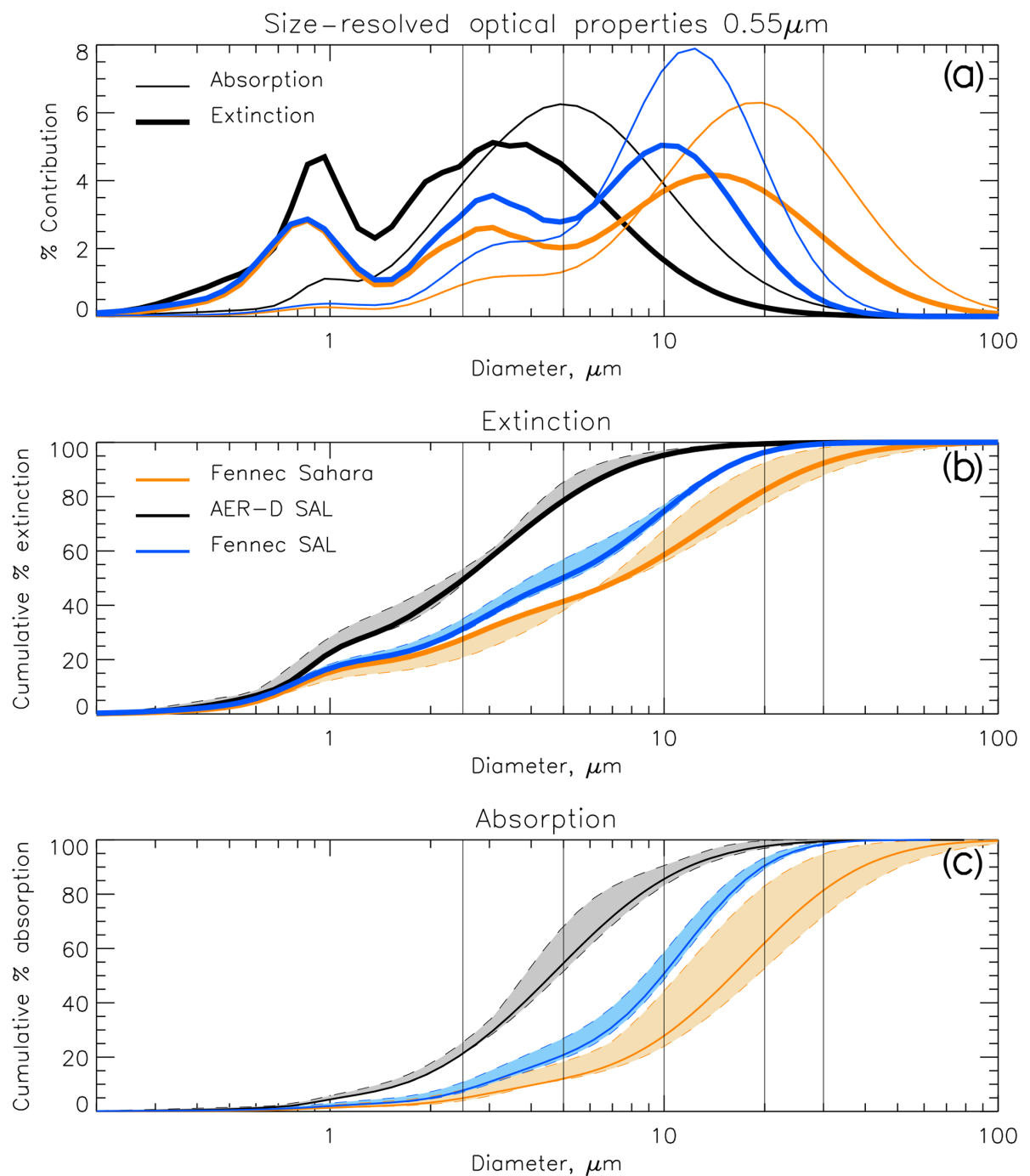

Figure 7. Size-resolved contribution to total absorption (thin lines) and extinction coefficient (bold lines) calculated for AER-D-SAL (black), Fennec-SAL (blue), and Fennec-Sahara (orange) at $0.55 \mu \mathrm{m}$ using the Colarco RI dataset. (a) Percentage contribution as a function of diameter, (b) cumulative percentage extinction coefficient as a function of diameter, and (c) cumulative percentage absorption coefficient as a function of diameter. In (b) and (c), shading bounded by dashed lines shows the uncertainty due to the range of RI datasets and PSD variability observed in each observational campaign. Vertical lines indicate diameters of 2.5, 5, 10, 20, and $30 \mu \mathrm{m}$.

peak contributions to absorption at the $12 \mu \mathrm{m}$ diameter. The size-resolved extinction and absorption curves are a direct reflection of the shape and abundance of the different PSDs shown in Fig. 2.

Figure $7 \mathrm{~b}$ and c clearly show that the cumulative optical properties increase much more slowly as a function of diameter for Fennec-Sahara compared to AER-D-SAL and Fennec-SAL due to the effect of the greater concentration of giant particles in Fennec-Sahara. Only representing dust particles sized up to $20 \mu \mathrm{m}$ in diameter, as in many dust models, results in $99 \%$ (99\%-100\%) of extinction in AER-DSAL and $96 \%$ (96\%-97\%) of extinction in Fennec-SAL but only $82 \%$ ( $77 \%-92 \%$ ) of the extinction over the Sahara (Fennec-Sahara) (see also Table 2). (Uncertainties are prop- agated from the range of PSDs and RI datasets.) Besides the impacts on extinction, there are impacts on absorption: representing only up to $20 \mu \mathrm{m}$ diameter results in $98 \%$ (97\%$100 \%)$ and $90 \%(87 \%-91 \%)$ of absorption being represented for AER-D-SAL and Fennec-SAL, respectively, but only $61 \%(52 \%-82 \%)$ of absorption being represented for Fennec-Sahara. Whilst total extinction drives AOD, absorption drives shortwave atmospheric heating and may subsequently impact regional circulation and the semi-direct effect. We note that these figures are lower-bound estimates of the impact of neglected absorption and extinction in dust models, since they only account for giant particles being excluded and not any underestimation of the coarse mode, which is included but poorly represented in models (e.g. Kok 


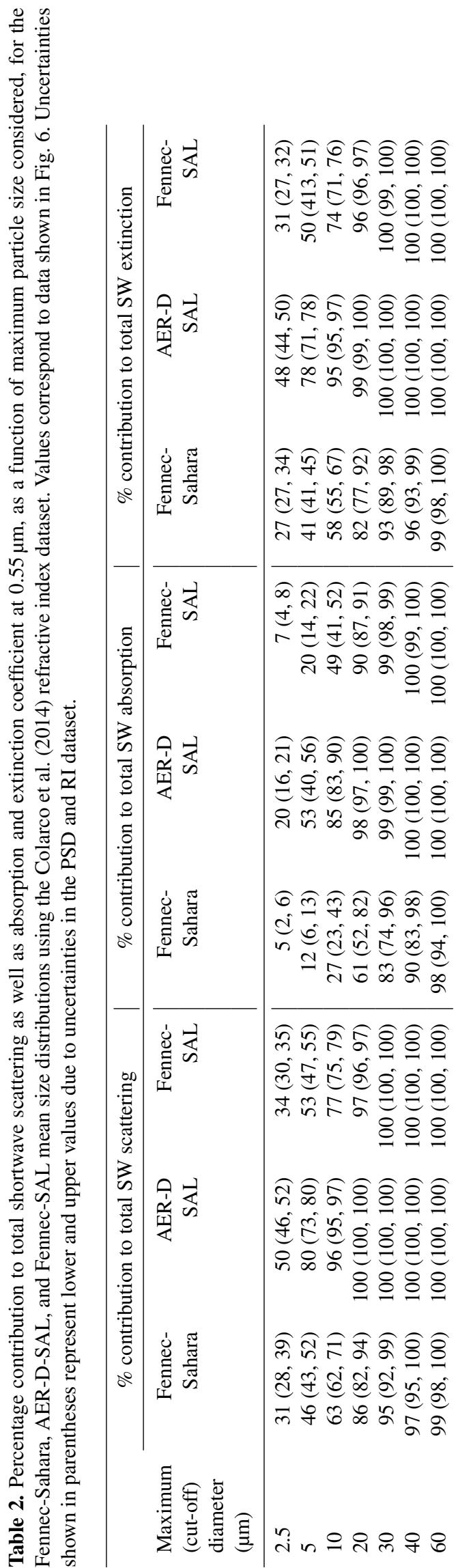

et al., 2017; Evan et al., 2014). It is also evident that by only representing sizes up to $2.5 \mu \mathrm{m}$, the majority of extinction is omitted (only $27 \%, 48 \%$, and $31 \%$ of extinction for FennecSahara, AER-D SAL, and Fennec-SAL, respectively, is captured). This result emphasizes that it is crucial to measure the coarse mode of dust aerosol in order to fully capture its optical properties, and dust observations sampling only $\mathrm{PM}_{2.5}$ or behind size-restricted aircraft inlets will not provide a realistic representation of dust size and the associated optical properties.

Figure 8 shows the size-resolved contribution to optical properties but for a wavelength of $10.8 \mu \mathrm{m}$, representing the longwave spectrum. As in Fig. 7, the three campaign mean PSDs have been used (from Fig. 2) with the Colarco RI. Panel a uses the Colarco RI exclusively, while in panels $b$ and $\mathrm{c}$ the shading represents the uncertainty for both the ranges of PSD shown in Fig. 2 and the different RI datasets. In Fig. 8a, for AER-D-SAL and Fennec-SAL, the main contribution to extinction comes from particles sized around 6 and $10 \mu \mathrm{m}$ in diameter, respectively, while the main contribution for Fennec-Sahara comes from particles sized $13 \mu \mathrm{m}$ in diameter. There is little difference in the relative contributions from scattering and absorption at this wavelength, with both contributing roughly equal amounts to the extinction (giving SSA values of $0.4-0.5$ ). Figure $8 \mathrm{~b}$ shows the same results cumulatively for extinction. As with the results from the shortwave spectrum, much of the extinction for AER-DSAL results from particles smaller than $10 \mu \mathrm{m}$ in diameter, while extinction for Fennec-SAL and Fennec-Sahara rises more slowly as a function of maximum diameter. Representing particles up to $20 \mu \mathrm{m}$ in diameter captures $98 \%$ (98\%$100 \%)$ and $94 \%(91 \%-94 \%)$ of the extinction for AER-DSAL and Fennec-SAL, respectively, but only $74 \%$ (66\%$89 \%$ ) for Fennec-Sahara (see also Table 3); i.e. $26 \%$ (11\%$34 \%$ ) of extinction at a wavelength of $10.8 \mu \mathrm{m}$ is missed by not including any representation of giant dust particles over the Sahara. Also, representing only up to $2.5 \mu \mathrm{m}$ (such as done for $\mathrm{PM}_{2.5}$ observations or many observations behind aircraft inlets) results in only $2 \%, 9 \%$, or $3 \%$ (for FennecSahara, AER-D SAL, and Fennec-SAL, respectively) of the total extinction being captured.

Sensitivity to the behaviour of the extinction curves at different wavelengths was tested, but no significant differences in the size-resolved behaviour was found, although the total extinction is different (as shown in Fig. 6). The cumulative curves for extinction and absorption at $10.8 \mu \mathrm{m}$ (Fig. $8 \mathrm{~b}$ and c) are also very similar for the longwave, since the scattering curve is similar to the absorption curve (in contrast to the shortwave spectrum). This is consistent with Sicard et al. (2014), who showed that the effects of dust LW scattering are significant and can cause up to a $50 \%$ underestimate in the dust radiative effect at the top of the atmosphere (TOA) if neglected (Dufresne et al., 2002; Coelho, 2006). 

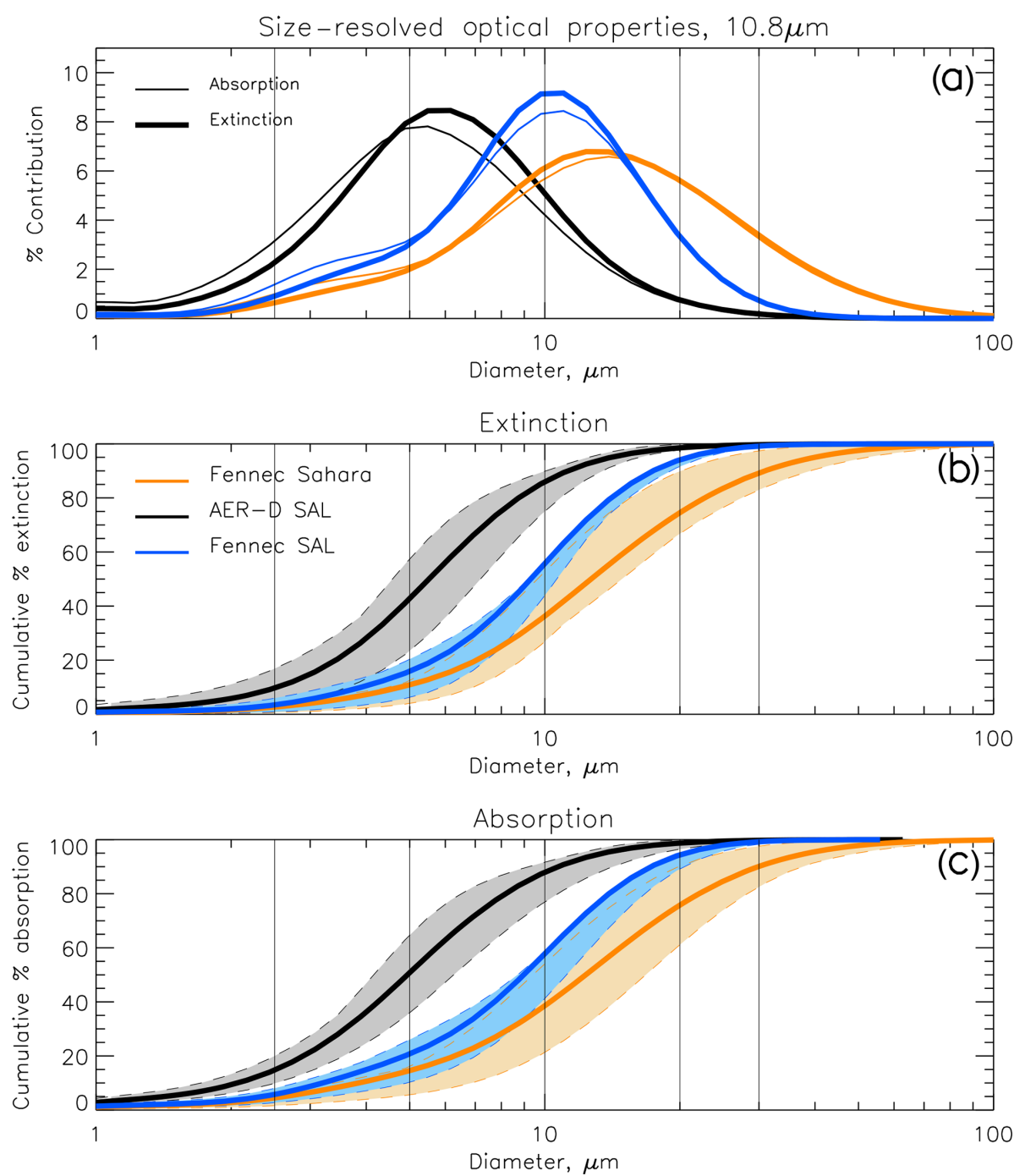

Figure 8. Size-resolved contribution to total absorption (thin lines) and extinction coefficient (bold lines) calculated for AER-D-SAL (black), Fennec-SAL (blue), and Fennec-Sahara (orange) at $10.8 \mu \mathrm{m}$ using the Volz RI dataset. (a) Percentage contribution as a function of diameter, (b) cumulative percentage extinction as a function of diameter, and (c) cumulative percentage absorption coefficient as a function of diameter. In (b) and (c), shading bounded by dashed lines shows the uncertainty due to the range of RI datasets and PSD variability observed in each observational campaign. Vertical lines indicate diameters of 2.5, 5, 10, 20, and $30 \mu \mathrm{m}$.

\subsection{The wider context of dust size and transport}

Figure 9 compares the AER-D-SAL and Fennec PSDs to previous aircraft observations of Saharan dust from the last 10 years, which fully observed the presence of the coarse and giant modes, at least up to the $20 \mu \mathrm{m}$ diameter: SAMUM1, SAMUM2, GERBILS, ADRIMED, and SALTRACE observations over the eastern and western Atlantic (see Table 1 for campaign references). For the SALTRACE PSDs, the submicron and supermicron data shown in Weinzierl et al. (2017) have been combined and collectively inverted, guaranteeing a consistent propagation of measurement uncertainties (in optical particle counter-response, optical particle properties, etc.) for the complete size range. Although other studies and fieldwork campaigns have also measured dust size distributions, here we focus on the coarse and giant modes and therefore only include studies which measured $d>20 \mu \mathrm{m}$ (and therefore do not include airborne observations from the DABEX, AMMA, and NAMMA campaigns). Details of the instrumentation operated in each fieldwork campaign, the relevant size limitations, and maximum size measured are provided in Table 1. We do not extrapolate the PSD modes beyond the size measured (e.g. $20 \mu \mathrm{m}$ for ADRIMED).

Overall, although the size distribution of dust shown in Fig. 9 varies, it is clear that there is always a significant contribution from dust particles sized $d>5 \mu \mathrm{m}$, and when dust is closer to the source, there is also a strong contribution from particles larger than $20 \mu \mathrm{m}$ in diameter. 


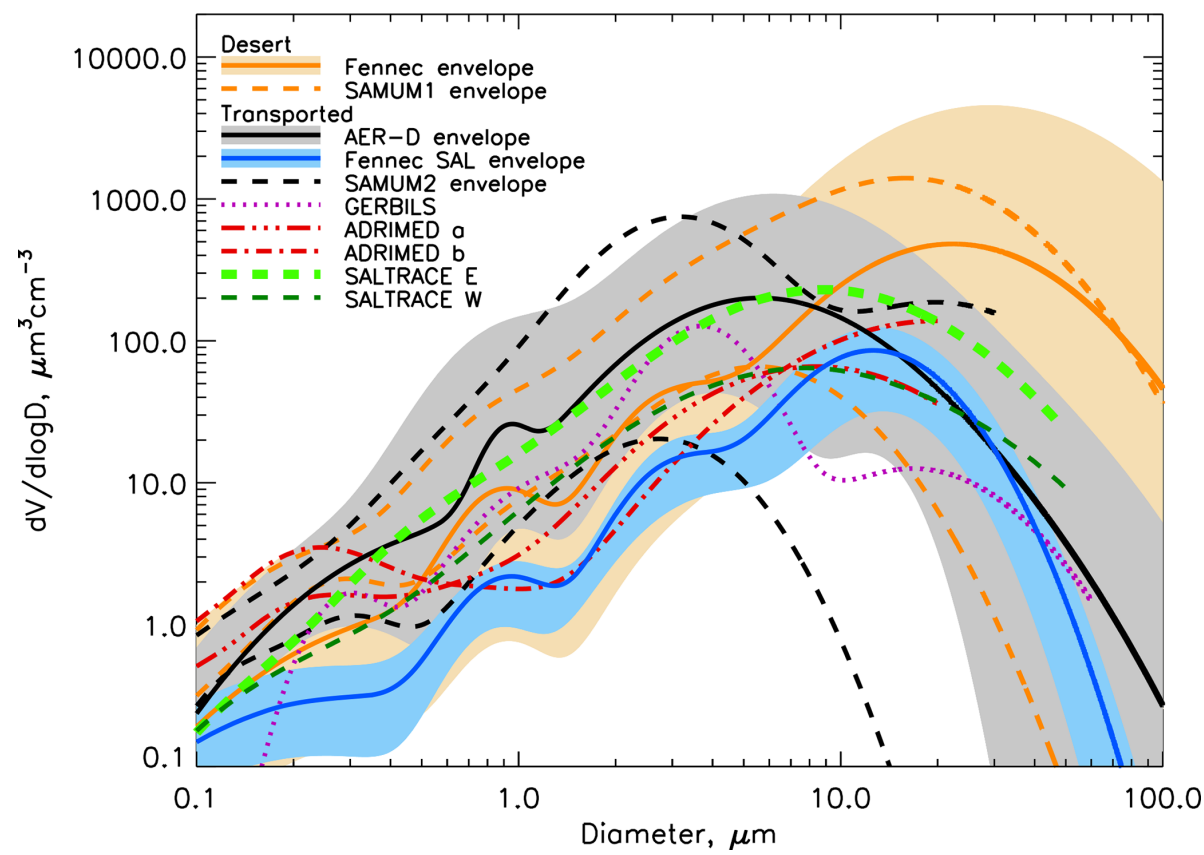

Figure 9. Lognormal ambient volume size distributions for recent airborne campaigns measuring Saharan dust extending to sizes larger than $20 \mu \mathrm{m}$ diameter. Observations close to dust sources are coloured orange. AER-D SAL mean and minimum-maximum envelope is shaded grey, Fennec-Sahara 10th percentile-maximum envelope is shaded orange, and Fennec-SAL minimum-maximum envelope is shaded blue as in Fig. 2. ADRIMED a and b represent dust above $3 \mathrm{~km}$ and beneath $3 \mathrm{~km}$, respectively. SALTRACE E and W represent observations over the eastern vs. western Atlantic. Lognormal curves are not shown at sizes above which measurements were made. See Table 1 for references for each campaign. SAMUM2 data are provided at standard temperature and pressure.

Clearly, the size distribution of Saharan dust can be highly variable. However, the two campaigns measuring the greatest abundance of coarse and giant particles with $d>10 \mu \mathrm{m}$ were Fennec-Sahara and SAMUM1, both taking observations in remote desert locations closer to dust sources. Volume mean diameters (VMDs) calculated from the mean PSDs (or envelope of PSDs for SAMUM) were also larger, at $21 \mu \mathrm{m}$ for Fennec-Sahara and 5-14 $\mu \mathrm{m}$ for SAMUM1. AER-D-SAL, GERBILS, SAMUM2, Fennec-SAL, and SALTRACE, further afield from dust sources, measured fewer giant particles, with maximum $\mathrm{d} V / \mathrm{d} \log D$ at around 3 to $5 \mu \mathrm{m}$. Giant particles were present at 20-30 $\mu \mathrm{m}$ but vastly reduced in volume concentration compared to Fennec-Sahara and SAMUM1. VMDs were lower at 3-4 $\mu \mathrm{m}$ (SAMUM2), $4 \mu \mathrm{m}$ (GERBILS), $5.6 \mu \mathrm{m}$ (AER-D-SAL), $12 \mu \mathrm{m}$ (Fennec-SAL), and 10-12 $\mu \mathrm{m}$ (SALTRACE E and W). These values represent the means of each campaign, and there will therefore be some additional overlap due to instrumental uncertainties and spatial and temporal variability within campaigns, though these data are not always available from the individual publications.

SAMUM2 represents dust transported over the Atlantic during winter at low altitudes. Although GERBILS observations were made over the west African continent during summer, it is likely that the dust events sampled represented aged regional dust with a depleted coarse mode (Haywood et al., 2011; Johnson and Osborne, 2011). ADRIMED also rep- resents transported dust, but over the Mediterranean Sea. At diameters of $20 \mu \mathrm{m}$ ADRIMED volume concentrations are similar to AER-D-SAL and SAMUM2, with a suggestion of a very large giant mode at even larger diameters (e.g. figures in Denjean et al., 2016). AER-D-SAL also represents transported dust and accordingly sits closer to GERBILS and SAMUM2 in Fig. 9 than to Fennec-Sahara and SAMUM1.

Figure 10 shows dust effective diameters as a function of estimated dust age since uplift. Firstly, Fig. 10a shows Fennec-Sahara and AER-D-SAL separated by dust events. Fennec-SAL is excluded because the range of dust ages is too broad for it to be a useful addition (Ryder et al., 2013a). During AER-D-SAL, the estimated dust age varied from 0.7 to $4.6 \mathrm{~d}$, while the range of effective diameters was very small, with flight means between 3.9 and $4.2 \mu \mathrm{m}$. Uncertainties in dust age for flights b928 and b934 are much larger due to the possibility of dust uplift from multiple sources along the transport pathway. Despite AER-D-SAL flights measuring dust with a range of transport times, the effective diameter showed only a variation of $5 \%$ about the mean of $4.0 \mu \mathrm{m}$. This contrasts sharply with observations of fresher dust from Fennec-Sahara for which $d_{\text {eff }}$ showed a decreasing trend with dust age. For Fennec-Sahara the freshest dust events (under $12 \mathrm{~h}$ since uplift) had mean $d_{\text {eff }}$ values of 8 to $13 \mu \mathrm{m}$, dropping to a mean of $6 \mu \mathrm{m}$ for dust aged around $2 \mathrm{~d}$. The addition of the data from AER-D-SAL suggests that in the bigger pic- 

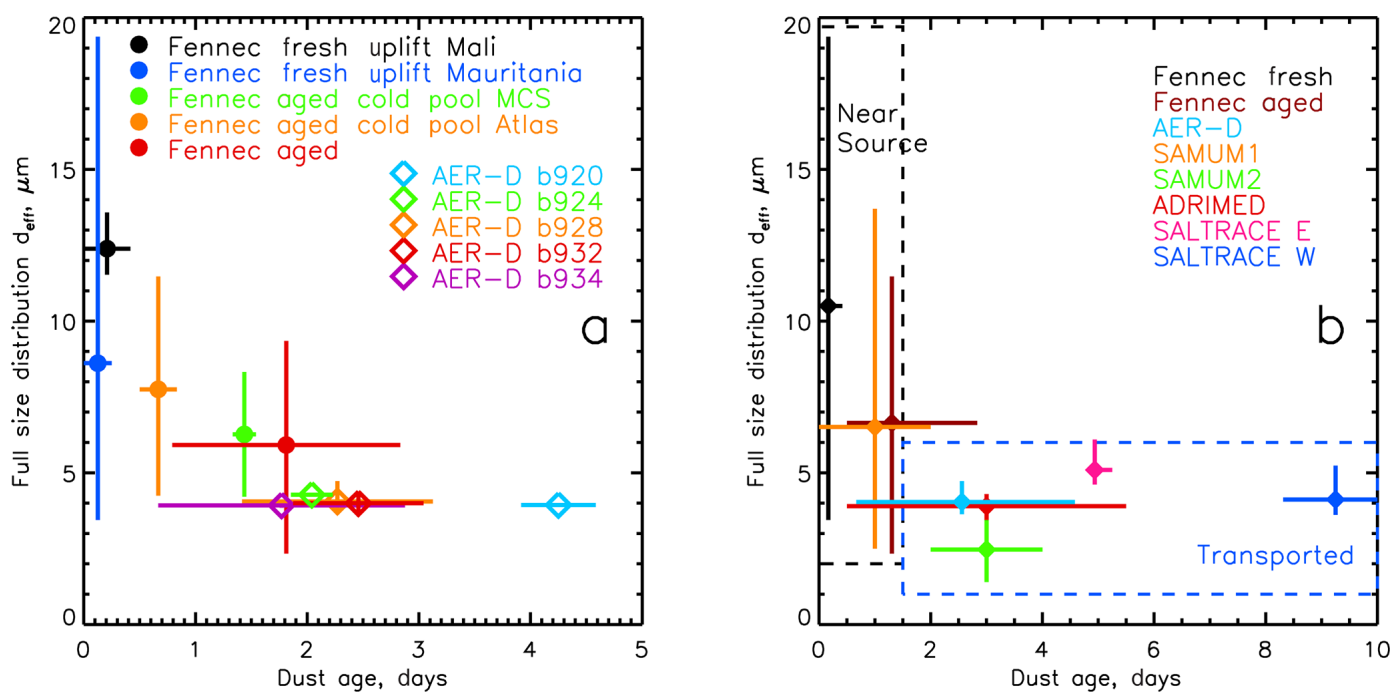

Figure 10. Aircraft observations of effective diameter for the full size distribution against dust age since uplift. (a) Fennec and AER-D: Fennec is categorized by type of dust event (see Ryder et al., 2013b), and AER-D data are separated by flight. (b) Saharan dust aircraft observations which fully measured coarse-mode size distribution up to at least $20 \mu \mathrm{m}$ in diameter; $d_{\text {eff }}$ is shown for the full size distribution or up to the maximum measurement diameter. Fennec-Sahara data are from Ryder et al. (2013b) and are identical to values shown in (a), but with data merged into fresh and aged dust categories. AER-D-SAL data represent the range of flight-by-flight data shown in (a). SAMUM1 data are from Weinzierl et al. (2009; Table 4). SAMUM2 data are from Weinzierl et al. (2011; Table 3). ADRIMED data are calculated from lognormal size distribution parameters in Denjean et al. (2016a) up to a maximum measurement size of $20 \mu \mathrm{m}$. SALTRACE (E and W: east and west) data are new calculations based on flight segments from Weinzierl et al. (2017). Data for (b) are given in the Supplement.

ture, dust size distributions change rapidly following initial uplift and transport, depositing some fraction of both coarse and giant particles, but after around $2 \mathrm{~d}$ size distribution appears to stabilize.

Figure 10b shows $d_{\text {eff }}$ against dust age since uplift for a range of airborne fieldwork campaigns, after Ryder et al. (2013a) (their Fig. 11) and Denjean et al. (2016) (also their Fig. 11). However, here we show $d_{\text {eff }}$ for the full size distribution ( 0.1 to $300 \mu \mathrm{m}$, or up to the maximum size measured in each campaign as shown in Fig. 9), since dust particles are present in both the submicron sizes (Formenti et al., 2011) and at $d>20 \mu \mathrm{m}$ (in contrast to Denjean et al. (2016), wherein $d_{\text {eff }}$ representing solely $1-20 \mu \mathrm{m}$ was presented, and consequently their values are higher). GERBILS data yield a mean effective diameter of around $3 \mu \mathrm{m}$ but are not included in Fig. 10b as no estimate of dust age was provided, though dust was likely to be relatively aged rather than fresh (personal communication, B. Johnson, 2017). This analysis is different to previous compilations of dust size observations (e.g. Reid et al., 2008; Formenti et al., 2011) because we (1) relate dust size to time since uplift, (2) only include airborne observations (since elevated dust properties are often different to those at the surface), (3) only include observations which measured at least up to the $20 \mu \mathrm{m}$ diameter unencumbered by inlet restrictions, and (4) incorporate more recent data, particularly that from Fennec, which provides data from the remote Sahara very close to dust uplift time, and SALTRACE, providing trans-Atlantic observations.
Figure 10b shows that the stabilization of the size distribution indicated in Fig. 10a still holds once other airborne data are included. Very large particles are evident immediately after uplift with high mean $d_{\text {eff }}$ values of 6 to $10 \mu \mathrm{m}$; $d_{\text {eff }}$ decreases rapidly until around $1.5 \mathrm{~d}$ after uplift, after which the observations suggest little change in $d_{\text {eff }}$ from around $2 \mathrm{~d}$ of transport onwards.

The range of $d_{\text {eff }}$ values at over $1.5 \mathrm{~d}$ of transport in Fig. $10 \mathrm{~b}$ is fairly wide (from 1.4 to $5.2 \mu \mathrm{m}$ ). SAMUM2 data show a slightly lower mean $d_{\text {eff }}$ value $(2.4 \mu \mathrm{m})$ compared to AER-D-SAL, ADRIMED, and SALTRACE (3.9 to $5.0 \mu \mathrm{m}$ ), though this may be a result of SAMUM2 observations being taken in the winter season when dust is transported by different meteorological mechanisms and uplifted to lower altitudes over the Sahara (McConnell et al., 2008; Knippertz and Todd, 2012; Tsamalis et al., 2013), which may influence size distribution differences. Focusing solely on the summertime campaign data, the spread of $d_{\text {eff }}$ values is very narrow, even after $9 \mathrm{~d}$ of transport across the Atlantic for SALTRACE-W, with $d_{\text {eff }}$ of $4.1 \mu \mathrm{m}$.

The stabilization of the size distribution is contrary to what would be expected from gravitational sedimentation theory. However, it is consistent with the findings of now numerous publications of individual field campaign dust size distributions, during which larger particles were observed than could be explained by gravitational settling alone (Ryder et al., 2013a, 2018; Denjean et al., 2016; Weinzierl et al., 2017; Stevenson et al., 2015; Gasteiger et al., 2017; van der Does 


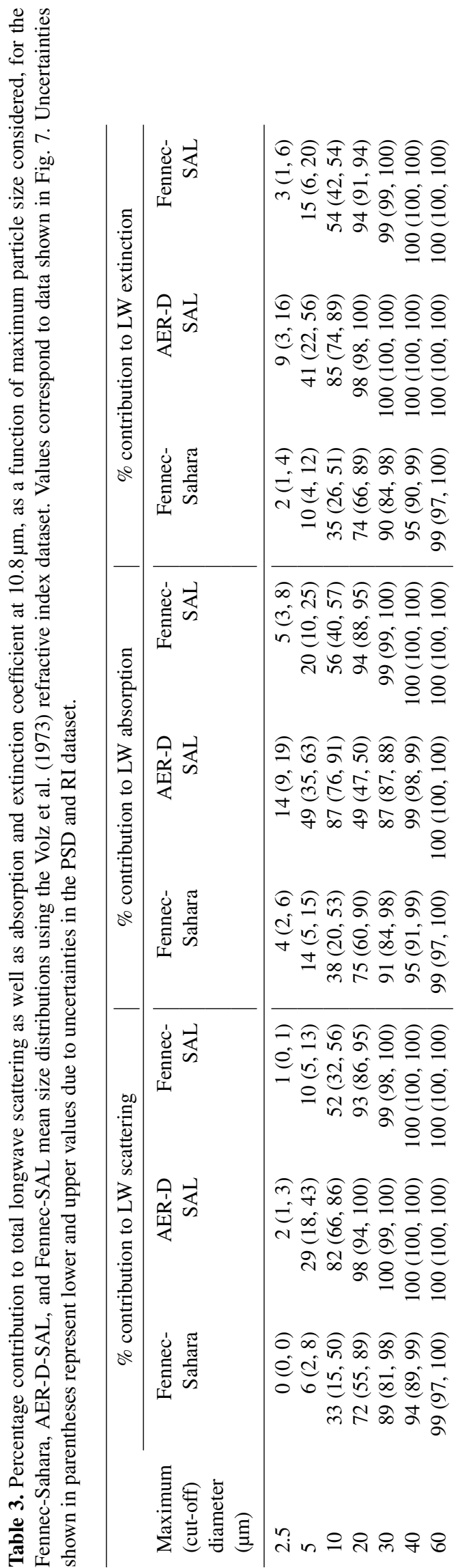

et al., 2018; Maring et al., 2003). Ryder et al. (2013a) examined the mechanisms for transport between fresh, aged, and SAL dust during Fennec-Sahara and found that sedimentation and dispersion were able to account for the loss of the accumulation- and giant-mode changes observed between the Saharan boundary layer and the SAL during FennecSahara but not for the coarse mode, which was retained to a greater degree than expected. Gasteiger et al. (2017) developed a simplified model for the long-range transport of Saharan dust aerosols over the Atlantic Ocean that was consistent with observations. Their results suggest that vertical mixing of the SAL air during the day (via convection caused by the absorption of sunlight) was likely to be an important factor in explaining the dust measurements at different stages of the transport. Van der Does et al. (2018) examined potential mechanisms for the long-range transport of giant dust particles and found it would be most likely under highly optimal conditions incorporating high levels of turbulence and strong winds, which may also allow for the electrical levitation of dust particles. Recently, Harrison et al. (2018) have observed charged dust during long-range transport to the UK, and Toth et al. (2019) and Harrison et al. (2018) have shown that electric fields are able to influence long-range-transported dust size distributions, enhancing the coarse particle concentration. Long-range transport could be further enhanced by repeated lifting of dust particles by deep convective clouds. However, van der Does et al. (2018) stress that the details of these mechanisms are mostly unquantified and require further research.

Denjean et al. (2016) suggest that during ADRIMED high turbulent updrafts and downdrafts of up to $5 \mathrm{~cm} \mathrm{~s}^{-1}$ (from model simulations) enabled large-particle lifetime enhancement. During AER-D-SAL, measured vertical velocities within the SAL were over $\pm 30 \mathrm{~cm} \mathrm{~s}^{-1}$ in all cases and sometimes up to $\pm 80 \mathrm{~cm} \mathrm{~s}^{-1}$. During Fennec-Sahara, vertical velocities were even larger: generally greater than $200 \mathrm{~cm} \mathrm{~s}^{-1}$ within the convective boundary layer (consistent with values from Marsham et al., 2013) and frequently over $50 \mathrm{~cm} \mathrm{~s}^{-1}$ up to $5 \mathrm{~km}$ of altitude. The gravitational settling velocity of a $10 \mu \mathrm{m}$ diameter particle would be 1.1 and $28 \mathrm{~cm} \mathrm{~s}^{-1}$ for a $100 \mu \mathrm{m}$ particle (Li and Osada, 2007). Therefore, it appears possible that high levels of atmospheric turbulence could have sustained the transport of larger particles for longer than expected by gravitational sedimentation. Additionally, during AER-D-SAL, vertical velocities were net positive in the SAL, supporting the possibility of solar absorption by the dust particles generating convection and daytime vertical mixing within the SAL (Gasteiger et al., 2017). The more absorbing nature of coarser particles in the solar spectrum would reinforce this mechanism. 


\section{Conclusions}

Several airborne observational campaigns have recently revealed the ubiquitous nature of coarse and giant dust particles within dusty air masses. Here, we present mean PSDs and their uncertainties from one Saharan dataset and two SAL datasets for which state-of-the art airborne measurements with consistent instrumentation were performed. These have been used to provide insights into how dust properties, particularly the coarse and giant modes, change with transport and how this impacts optical properties.

We have contrasted the mean airborne ambient size distributions of dust measured over the Sahara during the Fennec fieldwork (both over the Sahara and in the SAL near the Canary Islands) with the more recent observations made during the AER-D fieldwork within the SAL. The observations utilize light shadowing techniques which allow for the measurement of giant-mode dust particles and avert some of the historical challenges of airborne measurements of dust. All datasets fully capture the coarse and giant dust particles up to sizes of $100 \mu \mathrm{m}$ (AER-D-SAL) and $300 \mu \mathrm{m}$ (Fennec). As expected, Fennec-Sahara shows a greater giant mode $(d>$ $20 \mu \mathrm{m})$ than AER-D-SAL and Fennec-SAL, but the AERD-SAL mean PSD shows a greater volume concentration at diameters smaller than $8 \mu \mathrm{m}$.

The vertical distribution of dust size shows that size distributions with an extremely strong giant mode (displaying $d_{\text {eff }}$ between 12 and $21 \mu \mathrm{m}$ ) are only observed at low altitudes over the Sahara (up to around $1 \mathrm{~km}$ ) and only for fresh events (under $12 \mathrm{~h}$ since uplift). However, for aged events (longer than $12 \mathrm{~h}$ since uplift), giant particles are still present in the PSD up to $5 \mathrm{~km}$ of altitude with large $d_{\text {eff }}$ values of 5 to $10 \mu \mathrm{m}$. Effective diameters in AER-D-SAL were homogeneous at around $4 \mu \mathrm{m}$ throughout the SAL.

Models often use mass concentration as a diagnostic of aerosol amount, and therefore we have provided these from observational data in order to facilitate model validation studies. Mass concentration decreases with height over the Sahara but is more homogeneous and well mixed in the vertical in the SAL. Over the Sahara, $93 \%$ of dust mass is constituted by particles sized larger than $5 \mu \mathrm{m}$ on average, and $40 \%$ of dust mass is constituted by particles sized larger than $20 \mu \mathrm{m}$. Since 5 and $20 \mu \mathrm{m}$ are the diameters at which models begin to underestimate coarse-mode concentrations and omit the giant mode, respectively, models will be omitting a very large fraction of mass over the Sahara. During individual events, models may be missing up to $60 \%$ of mass by excluding dust sizes greater than $20 \mu \mathrm{m}$. Over the SAL, the fraction of mass omitted is smaller compared to the Sahara but potentially still important: $61 \%$ to $89 \%$ of dust mass is constituted by sizes over $5 \mu \mathrm{m}$ and $2 \%$ to $12 \%$ by sizes over $20 \mu \mathrm{m}$. This misrepresentation of dust mass in models will have a subsequent impact on the influence of dust in biogeochemical cycles and on human health and air quality. Other processes, which were not examined directly here, such as the role of coarse and gi- ant particles as ice-nucleating particles or cloud condensation nuclei, which affect the impact of dust on cloud development, will also be affected by model underrepresentation of coarse and giant dust particles.

The size-resolved contribution of the different PSDs to the extinction coefficient has also been calculated. By excluding particles larger than $20 \mu \mathrm{m}$ in diameter, as in many dust models, $18 \%(8 \%-23 \%)$ of extinction at a wavelength of $0.55 \mu \mathrm{m}$ will be omitted over the Sahara and $1 \%-4 \%(0 \%-$ $4 \%$ ) will be omitted in the SAL. (Ranges correspond to mean values for both SAL campaigns, and values in parentheses represent the range of uncertainty due to both PSD variability and the RI dataset.) Similarly, for absorption at $0.55 \mu \mathrm{m}$, excluding the giant mode will omit $39 \%(18 \%-48 \%)$ over the Sahara and $2 \%-10 \%(0 \%-13 \%)$ over the SAL. In the longwave spectrum at $10.8 \mu \mathrm{m}$, we find that only representing particles sized up to the $20 \mu \mathrm{m}$ diameter omits $26 \%$ (11\%$34 \%)$ of the extinction over the Sahara and $2 \%$ to $6 \%(0 \%-$ $9 \%$ ) of the extinction over the SAL.

The extinction coefficient profile determines the aerosol optical depth and the direct radiative effect of dust, while the absorption profile determines the semi-direct effect, impacts dust-driven shortwave atmospheric heating, and may subsequently impact regional circulation (Perlwitz and Miller, 2010; Solmon et al., 2012; Woodage and Woodward, 2014). Our results suggest that the missing extinction and absorption in models will therefore alter the impact of dust in models. Omitting the giant mode results in a greater omission of the longwave extinction than of the shortwave. Additionally, in the shortwave, the omission of absorption from the giant mode has the most impact. Since both these processes lead to a warming of the Earth-atmosphere system, this suggests that models are likely to be underestimating the warming influence of dust, with the radiative forcing due to aerosol(dust)-radiation interactions estimated to be $-0.1 \mathrm{~W} \mathrm{~m}^{-2}(-0.3$ to +0.1$)$ in the latest IPCC report (IPCC, 2013).

Additionally, these figures are lower-bound estimates of the impact of neglected absorption and extinction in dust models, since they only account for giant particles being excluded and not any additional underestimation of the coarse mode, which is included but poorly represented in models (e.g. Kok et al., 2017; Evan et al., 2014). Both excluding giant particles and underrepresenting the concentrations of coarse and giant particles will lead to more important consequences over the Sahara compared to in the SAL.

This work makes the assumption that dust particles are spherical for the optical property calculations in order to enable multiple rapid computations. This assumption is likely to have little impact in the longwave spectrum, since the size parameter is smaller. In the shortwave, our results represent a lower bound for the impact of the coarser dust: Kok et al. (2017) show that non-spherical dust increases extinction efficiency by $50 \%$ for coarse particles. Additionally, most climate models still assume spherical dust properties. Mea- 
suring the aspect ratio across the full size range from in situ measurements remains a challenging process. For the field campaigns studied here, aspect ratios were available only for a few samples from AER-D (Ryder et al., 2018), and future work will consider dust shape during Fennec. We emphasize the need for further work to obtain observations of dust particle shape, particularly across the full size range of dust as presented here, and to calculate the optical properties for non-spherical dust across all size and spectral ranges, which requires extensive computing resources.

Another important factor for consideration is that the Fennec and AER-D observations are taken in summertime when Saharan and SAL dust loadings are at a maximum, and coarse and giant particles are also present in a greater fraction due to strong convection lifting dust up to high altitudes over the Sahara, enabling further transport of the larger dust particles (e.g. McConnell et al., 2008; van der Does et al., 2016). This is also reflected in the slightly lower sizes seen in SAMUM2 during winter. Therefore, the impact of coarse and giant dust particles on mass concentrations and radiative effects presented here should be viewed as an upper bound within the seasonal cycle of dust.

Overall, the three main uncertainties impacting this work are the exclusion of any underestimation of the coarse mode (defined here as $2.5<d<20 \mu \mathrm{m}$ ) by models (in addition to the exclusion of the giant mode, $d>20 \mu \mathrm{m}$ ), a spherical assumption for scattering calculations, and the use of data based on summertime dust transport. The former two mean that our results of the impact of coarse and giant dust particles are underestimates, while the latter means our results are overestimates compared to an annual average.

Finally, we put the Fennec-Sahara and AER-D-SAL PSDs in the context of other airborne campaigns of the last 10 years which have measured Saharan dust and included measurements larger than $10 \mu \mathrm{m}$ in diameter. The two sets of dust observations closest to dust sources, Fennec-Sahara and SAMUM1, show a clear presence of giant particles influencing the shape of the PSDs, while those measuring transported dust showed a steeper drop-off of the PSD and lower total concentrations. Despite this, there is still a significant presence of coarse and giant particles in the "transported" size distributions. Evaluating the effective diameter for each field campaign against dust age since uplift time reveals what appear to be two regimes of dust transport: firstly, $d_{\text {eff }}$ drops off rapidly during initial transport within the first $36 \mathrm{~h}$, and secondly, $d_{\text {eff }}$ appears very stable despite significant amounts of transport between around 2 and $10 \mathrm{~d}$.

It is clear that mineral dust coarse and giant modes are retained to a much greater degree than expected from gravitational sedimentation alone. The processes behind this are still unclear (e.g. van der Does et al., 2018). Potential explanations which warrant further study include variations in fall speed dependent on particle composition, density, shape and orientation, turbulent and convective mixing, triboelectric charging, and radiative lofting impacts of the coarse and giant particles. Similar processes and uncertainties also apply to the atmospheric transport of volcanic ash, wherein similar unexplained long-range transport of coarse and giant particles has been observed (e.g. Stevenson et al., 2015; Beckett et al., 2015; Saxby et al., 2018).

Overall, climate models generally do not incorporate dust particles sized over $20 \mu \mathrm{m}$. Historically this has been because of the assumption that larger particles are deposited rapidly. This work suggests that although particles larger than $20 \mu \mathrm{m}$ do exist up to high altitudes even in transported dust, it is over the Sahara that the contribution of this size range to total mass, absorption, and extinction are most significant. For transported dust in the SAL, the size distribution has evolved such that the giant particles contribute only a small amount to total extinction and dust mass concentration. However, models begin to underestimate dust concentrations at sizes well below this, from $5 \mu \mathrm{m}$ upwards. Our results show that dust particles in this size range (diameters 5 to $20 \mu \mathrm{m}$ ) are still highly prevalent and contribute a large amount to extinction and dust mass in the SAL as well as over the Sahara, so better representation of the coarse-mode size distribution within dust models is also an area for improvement.

In the absence of other mechanisms and explanations, it is natural that to date climate models have employed some form of gravitational settling for the dry deposition of dust. However, other mechanisms must be occurring in the real world in order to transport coarse and giant particles as far and for as long as detected in observations. Therefore, further work, ideally combining observations and modelling efforts, in order to explain this transport is required.

Data availability. We are in the process of uploading the campaign mean data presented here to the Centre for Environmental Data Analysis (CEDA). Flight-by-flight aircraft data are publicly available at https://catalogue.ceda.ac.uk/uuid/ affe775e8d8890a4556aec5bc4e0b45c, last access: 2 December 2019, Smith, 2004.

Supplement. The supplement related to this article is available online at: https://doi.org/10.5194/acp-19-15353-2019-supplement.

Author contributions. CLR designed and carried out the analysis and wrote the paper. EJH discussed the methodology and results. SALTRACE size distributions were provided by AW and BW. SALTRACE dust age estimates were provided by PS and AP. All authors read and commented on the paper.

Competing interests. The authors declare that they have no conflict of interest. 
Acknowledgements. FLEXPART output was generated using ERA5 data (Copernicus Climate Change Service, 2018) accessed through the ECMWF's Meteorological Archival and Retrieval System (MARS). SALTRACE dust age estimates were calculated using Copernicus Atmosphere Monitoring Service (2018) information. Petra Seibert and Anne Philipp thank the Austrian Meteorological Service, ZAMG, for access to MARS. Bernadett Weinzierl, Anne Philipp, and Adrian Walser were funded by the European Research Council (ERC) under the European Union's Horizon 2020 research and innovation framework programme under grant agreement no. 640458 (A-LIFE). The SALTRACE research flights were funded by the Helmholtz Association under grant VH-NG-606 (Helmholtz-Hochschul-Nachwuchsforschergruppe AerCARE) and by DLR. The authors are grateful to Margaret Woodage for comments on the paper and James Banks for discussions relating to longwave dust radiative interactions.

Financial support. This research has been supported by a NERC independent research fellowship grant (grant no. NE/M018288/1).

Review statement. This paper was edited by Stelios Kazadzis and reviewed by three anonymous referees.

\section{References}

Ansmann, A., Petzold, A., Kandler, K., Tegen, I., Wendisch, M., Müller, D., Weinzierl, B., Müller, T., and Heintzenberg, J.: Saharan Mineral Dust Experiments SAMUM-1 and SAMUM-2: what have we learned?, Tellus B, 63, 403-429, https://doi.org/10.1111/j.1600-0889.2011.00555.x, 2011.

Ansmann, A., Rittmeister, F., Engelmann, R., Basart, S., Jorba, O., Spyrou, C., Remy, S., Skupin, A., Baars, H., Seifert, P., Senf, F., and Kanitz, T.: Profiling of Saharan dust from the Caribbean to western Africa - Part 2: Shipborne lidar measurements versus forecasts, Atmos. Chem. Phys., 17, 14987-15006, https://doi.org/10.5194/acp-17-14987-2017, 2017.

Balkanski, Y., Schulz, M., Claquin, T., and Guibert, S.: Reevaluation of Mineral aerosol radiative forcings suggests a better agreement with satellite and AERONET data, Atmos. Chem. Phys., 7, 81-95, https://doi.org/10.5194/acp-7-81-2007, 2007.

Banks, J. R., Schepanski, K., Heinold, B., Hünerbein, A., and Brindley, H. E.: The influence of dust optical properties on the colour of simulated MSG-SEVIRI Desert Dust infrared imagery, Atmos. Chem. Phys., 18, 9681-9703, https://doi.org/10.5194/acp18-9681-2018, 2018.

Bauer, S. E., Balkanski, Y., Schulz, M., Hauglustaine, D. A., and Dentener, F.: Global modeling of heterogeneous chemistry on mineral aerosol surfaces: Influence on tropospheric ozone chemistry and comparison to observations, J. Geophys. Res.-Atmos., 109, D02304, https://doi.org/10.1029/2003jd003868, 2004.

Beckett, F. M., Witham, C. S., Hort, M. C., Stevenson, J. A., Bonadonna, C., and Millington, S. C.: Sensitivity of dispersion model forecasts of volcanic ash clouds to the physical characteristics of the particles, J. Geophys. Res.-Atmos., 120, 1163611652, https://doi.org/10.1002/2015jd023609, 2015.
Betzer, P. R., Carder, K. L., Duce, R. A., Merrill, J. T., Tindale, N. W., Uematsu, M., Costello, D. K., Young, R. W., Feely, R. A., Breland, J. A., Bernstein, R. E., and Greco, A. M.: Long-Range Transport of Giant Mineral Aerosol-Particles, Nature, 336, 568571, https://doi.org/10.1038/336568a0, 1988.

Brindley, H., Knippertz, P., Ryder, C., and Ashpole, I.: A critical evaluation of the ability of the Spinning Enhanced Visible and Infrared Imager (SEVIRI) thermal infrared red-green-blue rendering to identify dust events: Theoretical analysis, J. Geophys. Res.-Atmos., 117, D07201, https://doi.org/10.1029/2011jd017326, 2012.

Chen, G., Ziemba, L. D., Chu, D. A., Thornhill, K. L., Schuster, G. L., Winstead, E. L., Diskin, G. S., Ferrare, R. A., Burton, S. P., Ismail, S., Kooi, S. A., Omar, A. H., Slusher, D. L., Kleb, M. M., Reid, J. S., Twohy, C. H., Zhang, H., and Anderson, B. E.: Observations of Saharan dust microphysical and optical properties from the Eastern Atlantic during NAMMA airborne field campaign, Atmos. Chem. Phys., 11, 723-740, https://doi.org/10.5194/acp-11-723-2011, 2011.

Coelho, D. C.: A New Estimate of the Components of the Earth's Longwave Radiation Budget, $\mathrm{PhD}$, Department of Meteorology, University of Reading, 89-116, 2006.

Colarco, P. R., Toon, O. B., Torres, O., and Rasch, P. J.: Determining the UV imaginary index of refraction of Saharan dust particles from Total Ozone Mapping Spectrometer data using a threedimensional model of dust transport, J. Geophys. Res.-Atmos., 107, D16, 4289, https://doi.org/10.1029/2001jd000903, 2002.

Colarco, P. R., Nowottnick, E. P., Randles, C. A., Yi, B. Q., Yang, P., Kim, K. M., Smith, J. A., and Bardeen, C. G.: Impact of radiatively interactive dust aerosols in the NASA GEOS-5 climate model: Sensitivity to dust particle shape and refractive index, J. Geophys. Res.-Atmos., 119, 753-786, https://doi.org/10.1002/2013jd020046, 2014.

d'Almeida, G. A., Koepke, P., and Shettle, E. P.: Atmospheric Aerosols: Global Climatology and Radiation Characteristics, A Deepak Pub, Hampton, VA, USA, 561 pp, 1991.

Denjean, C., Caquineau, S., Desboeufs, K., Laurent, B., Maille, M., Rosado, M. Q., Vallejo, P., Mayol-Bracero, O. L., and Formenti, P.: Long-range transport across the Atlantic in summertime does not enhance the hygroscopicity of African mineral dust, Geophys. Res. Lett., 42, 7835-7843, https://doi.org/10.1002/2015g1065693, 2015.

Denjean, C., Cassola, F., Mazzino, A., Triquet, S., Chevaillier, S., Grand, N., Bourrianne, T., Momboisse, G., Sellegri, K., Schwarzenbock, A., Freney, E., Mallet, M., and Formenti, P.: Size distribution and optical properties of mineral dust aerosols transported in the western Mediterranean, Atmos. Chem. Phys., 16, 1081-1104, https://doi.org/10.5194/acp16-1081-2016, 2016.

Di Biagio, C., Formenti, P., Balkanski, Y., Caponi, L., Cazaunau, M., Pangui, E., Journet, E., Nowak, S., Caquineau, S., Andreae, M. O., Kandler, K., Saeed, T., Piketh, S., Seibert, D., Williams, E., and Doussin, J.-F.: Global scale variability of the mineral dust long-wave refractive index: a new dataset of in situ measurements for climate modeling and remote sensing, Atmos. Chem. Phys., 17, 1901-1929, https://doi.org/10.5194/acp17-1901-2017, 2017. 
Diaz-Hernandez, J. L. and Sanchez-Navas, A.: Saharan dust outbreaks and iberulite episodes, J. Geophys. Res.-Atmos., 121, 7064-7078, https://doi.org/10.1002/2016jd024913, 2016.

Diehl, K., Debertshäuser, M., Eppers, O., Schmithüsen, H., Mitra, S. K., and Borrmann, S.: Particle surface area dependence of mineral dust in immersion freezing mode: investigations with freely suspended drops in an acoustic levitator and a vertical wind tunnel, Atmos. Chem. Phys., 14, 12343-12355, https://doi.org/10.5194/acp-14-12343-2014, 2014.

Draxler, R. R. and Hess, G. D.: An overview of the HYSPLIT_4 modeling system of trajectories, dispersion, and deposition, Aust. Meteorol. Mag., 47, 295-308, 1998.

Dufresne, J. L., Gautier, C., Ricchiazzi, P., and Fouquart, Y.: Longwave scattering effects of mineral aerosols, J. Atmos. Sci., 59, 1959-1966, https://doi.org/10.1175/15200469(2002)059<1959:Lseoma>2.0.Co;2, 2002.

Evan, A. T., Flamant, C., Fiedler, S., and Doherty, O.: An analysis of aeolian dust in climate models, Geophys. Res. Lett., 41, 59966001, https://doi.org/10.1002/2014g1060545, 2014.

Feingold, G., Cotton, W. R., Kreidenweis, S. M., and Davis, J. T.: The impact of giant cloud condensation nuclei on drizzle formation in stratocumulus: Implications for cloud radiative properties, J. Atmos. Sci., 56, 4100-4117, https://doi.org/10.1175/15200469(1999)056<4100:Tiogcc>2.0.Co;2, 1999.

Formenti, P., Schütz, L., Balkanski, Y., Desboeufs, K., Ebert, M., Kandler, K., Petzold, A., Scheuvens, D., Weinbruch, S., and Zhang, D.: Recent progress in understanding physical and chemical properties of African and Asian mineral dust, Atmos. Chem. Phys., 11, 8231-8256, https://doi.org/10.5194/acp11-8231-2011, 2011.

Fouquart, Y., Bonnel, B., Brogniez, G., Buriez, J. C., Smith, L., Morcrette, J. J., and Cerf, A.: Observations of Saharan Aerosols - Results of Eclats Field Experiment, 2. Broad-Band Radiative Characteristics of the Aerosols and Vertical Radiative Flux Divergence, J. Clim. Appl. Meteorol., 26, 38-52, https://doi.org/10.1175/15200450(1987)026<0038:Oosaro >2.0.Co;2, 1987.

Gasteiger, J., Groß, S., Sauer, D., Haarig, M., Ansmann, A., and Weinzierl, B.: Particle settling and vertical mixing in the Saharan Air Layer as seen from an integrated model, lidar, and in situ perspective, Atmos. Chem. Phys., 17, 297-311, https://doi.org/10.5194/acp-17-297-2017, 2017.

Goudie, A. S. and Middleton, N. J.: Saharan dust storms: nature and consequences, Earth.-Sci. Rev., 56, 179-204, https://doi.org/10.1016/S0012-8252(01)00067-8, 2001.

Hansen, J. E. and Travis, L. D.: Light-Scattering in Planetary Atmospheres, Space Sci. Rev., 16, 527-610, https://doi.org/10.1007/Bf00168069, 1974.

Harrison, R. G., Nicoll, K. A., Marlton, G. J., Ryder, C. L., and Bennett, A. J.: Saharan dust plume charging observed over the UK, Environ. Res. Lett., 13, 054018, https://doi.org/10.1088/17489326/aabcd9, 2018.

Haywood, J. M., Francis, P. N., Glew, M. D., and Taylor, J. P.: Optical properties and direct radiative effect of Saharan dust: A case study of two Saharan dust outbreaks using aircraft data, J. Geophys. Res.-Atmos., 106, 18417-18430, https://doi.org/10.1029/2000jd900319, 2001.

Hess, M., Koepke, P., and Schult, I.: Optical properties of aerosols and clouds: The software package OPAC, B. Am.
Meteorol. Soc., 79, 831-844, https://doi.org/10.1175/15200477(1998)079<0831:Opoaac>2.0.Co;2, 1998.

Hoose, C. and Möhler, O.: Heterogeneous ice nucleation on atmospheric aerosols: a review of results from laboratory experiments, Atmos. Chem. Phys., 12, 9817-9854, https://doi.org/10.5194/acp-12-9817-2012, 2012.

Huneeus, N., Schulz, M., Balkanski, Y., Griesfeller, J., Prospero, J., Kinne, S., Bauer, S., Boucher, O., Chin, M., Dentener, F., Diehl, T., Easter, R., Fillmore, D., Ghan, S., Ginoux, P., Grini, A., Horowitz, L., Koch, D., Krol, M. C., Landing, W., Liu, X., Mahowald, N., Miller, R., Morcrette, J.-J., Myhre, G., Penner, J., Perlwitz, J., Stier, P., Takemura, T., and Zender, C. S.: Global dust model intercomparison in AeroCom phase I, Atmos. Chem. Phys., 11, 7781-7816, https://doi.org/10.5194/acp11-7781-2011, 2011.

Ibrahim, S., Romanias, M. N., Alleman, L. Y., Zeineddine, M. N., Angeli, G. K., Trikalitis, P. N., and Thevenet, F.: Water Interaction with Mineral Dust Aerosol: Particle Size and Hygroscopic Properties of Dust, ACS Earth Space Chem., 2, 376-386, https://doi.org/10.1021/acsearthspacechem.7b00152, 2018.

IPCC: IPCC, 2013: Summary for Policymakers, in: Climate Change 2013: The Physical Science Basis, Contribution of Working Group I to the Fifth Assessment Report of the Intergovernmental Panel on Climate Change Cambridge, 29 pp., 2013.

Jaenicke, R. and Schutz, L.: Comprehensive Study of Physical and Chemical Properties of Surface Aerosols in Cape-VerdeIslands Region, J. Geophys. Res.-Oc. Atm., 83, 3585-3599, https://doi.org/10.1029/JC083iC07p03585, 1978.

Jickells, T. D., An, Z. S., Andersen, K. K., Baker, A. R., Bergametti, G., Brooks, N., Cao, J. J., Boyd, P. W., Duce, R. A., Hunter, K. A., Kawahata, H., Kubilay, N., laRoche, J., Liss, P. S., Mahowald, N., Prospero, J. M., Ridgwell, A. J., Tegen, I., and Torres, R.: Global iron connections between desert dust, ocean biogeochemistry, and climate, Science, 308, 67-71, 2005.

Johnson, B. T. and Osborne, S. R.: Physical and optical properties of mineral dust aerosol measured by aircraft during the GERBILS campaign, Q. J. Roy. Meteor. Soc., 137, 1117-1130, https://doi.org/10.1002/Qj.777, 2011.

Kandler, K., Schutz, L., Deutscher, C., Ebert, M., Hofmann, H., Jäckel, S., Jaenicke, R., Knippertz, P., Lieke, K., Massling, A., Petzold, A., Schladitz, A., Weinzierl, B., Wiedensohler, A., Zorn, S., and Weinbruch, S.: Size distribution, mass concentration, chemical and mineralogical composition and derived optical parameters of the boundary layer aerosol at Tinfou, Morocco, during SAMUM 2006, Tellus B, 61, 32-50, https://doi.org/10.1111/j.1600-0889.2008.00385.x, 2009.

Kim, D., Chin, M., Yu, H., Eck, T. F., Sinyuk, A., Smirnov, A., and Holben, B. N.: Dust optical properties over North Africa and Arabian Peninsula derived from the AERONET dataset, Atmos. Chem. Phys., 11, 10733-10741, https://doi.org/10.5194/acp-1110733-2011, 2011.

Kinne, S., Schulz, M., Textor, C., Guibert, S., Balkanski, Y., Bauer, S. E., Berntsen, T., Berglen, T. F., Boucher, O., Chin, M., Collins, W., Dentener, F., Diehl, T., Easter, R., Feichter, J., Fillmore, D., Ghan, S., Ginoux, P., Gong, S., Grini, A., Hendricks, J., Herzog, M., Horowitz, L., Isaksen, I., Iversen, T., Kirkevåg, A., Kloster, S., Koch, D., Kristjansson, J. E., Krol, M., Lauer, A., Lamarque, J. F., Lesins, G., Liu, X., Lohmann, U., Montanaro, V., Myhre, G., Penner, J., Pitari, G., Reddy, S., Seland, O., Stier, P., Take- 
mura, T., and Tie, X.: An AeroCom initial assessment - optical properties in aerosol component modules of global models, Atmos. Chem. Phys., 6, 1815-1834, https://doi.org/10.5194/acp-61815-2006, 2006.

Knippertz, P. and Todd, M. C.: Mineral Dust Aerosols over the Sahara: Meteorological Controls on Emission and Transport and Implications for Modeling, Rev. Geophys., 50, 2011RG000362, https://doi.org/10.1029/2011rg000362, 2012.

Kok, J. F., Ridley, D. A., Zhou, Q., Miller, R. L., Zhao, C., Heald, C. L., Ward, D. S., Albani, S., and Haustein, K.: Smaller desert dust cooling effect estimated from analysis of dust size and abundance, Nat. Geosci., 10, 274-278, https://doi.org/10.1038/Ngeo2912, 2017.

Kulkarni, P., Baron, P. A., and Willeke, K.: in: Aerosol Measurement: Principles, Techniques, and Applications, 3 Edn., edited by: Kulkarni, P., John Wiley \& Sons, Hoboken, New Jersey, 310, 2011.

Kumar, P., Sokolik, I. N., and Nenes, A.: Cloud condensation nuclei activity and droplet activation kinetics of wet processed regional dust samples and minerals, Atmos. Chem. Phys., 11, 8661-8676, https://doi.org/10.5194/acp-11-8661-2011, 2011.

Lavaysse, C., Chaboureau, J. P., and Flamant, C.: Dust impact on the West African heat low in summertime, Q. J. Roy. Meteor. Soc., 137, 1227-1240, https://doi.org/10.1002/Qj.844, 2011.

Lensky, I. M. and Rosenfeld, D.: Clouds-Aerosols-Precipitation Satellite Analysis Tool (CAPSAT), Atmos. Chem. Phys., 8, 6739-6753, https://doi.org/10.5194/acp-8-6739-2008, 2008.

Li, J. M. and Osada, K. Z.: Preferential settling of elongated mineral dust particles in the atmosphere, Geophys. Res. Lett., 34, L17807, https://doi.org/10.1029/2007gl030262, 2007.

Liao, H. and Seinfeld, J. H.: Radiative forcing by mineral dust aerosols: sensitivity to key variables, J. Geophys. Res.-Atmos., 103, 31637-31645, 1998.

Lohmann, U., Luond, F., and Mahrt, F.: An Introduction to Clouds: From the Microscale to Climate, Cambridge University Press, Cambridge, UK, 382 pp., 2016.

Mahowald, N., Albani, S., Kok, J. F., Engelstaeder, S., Scanza, R., Ward, D. S., and Flanner, M. G.: The size distribution of desert dust aerosols and its impact on the Earth system, Aeolian. Res., 15, 53-71, https://doi.org/10.1016/j.aeolia.2013.09.002, 2014.

Maring, H., Savoie, D. L., Izaguirre, M. A., Custals, L., and Reid, J. S.: Mineral dust aerosol size distribution change during atmospheric transport, J. Geophys. Res.-Atmos., 108, 8592, https://doi.org/10.1029/2002jd002536, 2003.

Marsham, J. H., Hobby, M., Allen, C. J. T., Banks, J. R., Bart, M., Brooks, B. J., Cavazos-Guerra, C., Engelstaedter, S., Gascoyne, M., Lima, A. R., Martins, J. V., McQuaid, J. B., O’Leary, A., Ouchene, B., Ouladichir, A., Parker, D. J., Saci, A., SalahFerroudj, M., Todd, M. C., and Washington, R.: Meteorology and dust in the central Sahara: Observations from Fennec supersite-1 during the June 2011 Intensive Observation Period, J. Geophys. Res.-Atmos., 118, 4069-4089, 10.1002/jgrd.50211, 2013.

McConnell, C. L., Highwood, E. J., Coe, H., Formenti, P., Anderson, B., Osborne, S., Nava, S., Desboeufs, K., Chen, G., and Harrison, M. A. J.: Seasonal variations of the physical and optical characteristics of Saharan dust: Results from the Dust Outflow and Deposition to the Ocean (DODO) experiment, J. Geophys. Res.-Atmos., 113, D14S05, https://doi.org/10.1029/2007jd009606, 2008.
Middleton, N., Tozer, P., and Tozer, B.: Sand and dust storms: underrated natural hazards, Disasters, 43, 390-409, https://doi.org/10.1111/disa.12320, 2018.

Middleton, N. J.: Desert dust hazards: A global review, Aeolian. Res., 24, 53-63, https://doi.org/10.1016/j.aeolia.2016.12.001, 2017.

NASA GES DISC Glossary: https://disc.gsfc.nasa.gov/information/ glossary?title=AerosolEffectiveRadius, last access: 4 October 2018 .

Neff, J. C., Reynolds, R. L., Munson, S. M., Fernandez, D., and Belnap, J.: The role of dust storms in total atmospheric particle concentrations at two sites in the western US, J. Geophys. Res.Atmos., 118, 11201-11212, https://doi.org/10.1002/jgrd.50855, 2013.

Osborne, S. R., Johnson, B. T., Haywood, J. M., Baran, A. J., Harrison, M. A. J., and McConnell, C. L.: Physical and optical properties of mineral dust aerosol during the Dust and Biomassburning Experiment, J. Geophys. Res.-Atmos., 113, D00C03, https://doi.org/10.1029/2007jd009551, 2008.

Otto, S., Trautmann, T., and Wendisch, M.: On realistic size equivalence and shape of spheroidal Saharan mineral dust particles applied in solar and thermal radiative transfer calculations, Atmos. Chem. Phys., 11, 4469-4490, https://doi.org/10.5194/acp11-4469-2011, 2011.

Pan, B. W., Wang, Y. A., Hu, J. X., Lin, Y., Hsieh, J. S., Logan, T., Feng, X. D., Jiang, J. H., Yung, Y. L., and Zhang, R. Y.: Impacts of Saharan Dust on Atlantic Regional Climate and Implications for Tropical Cyclones, J. Climate, 31, 7621-7644, https://doi.org/10.1175/Jcli-D-16-0776.1, 2018.

Perlwitz, J. and Miller, R. L.: Cloud cover increase with increasing aerosol absorptivity: A counterexample to the conventional semidirect aerosol effect, J. Geophys. Res.-Atmos., 115, D08203, https://doi.org/10.1029/2009jd012637, 2010.

Petters, M. D. and Kreidenweis, S. M.: A single parameter representation of hygroscopic growth and cloud condensation nucleus activity, Atmos. Chem. Phys., 7, 1961-1971, https://doi.org/10.5194/acp-7-1961-2007, 2007.

Reid, J. S., Reid, E. A., Walker, A., Piketh, S., Cliff, S., Al Mandoos, A., Tsay, S. C., and Eck, T. F.: Dynamics of southwest Asian dust particle size characteristics with implications for global dust research, J. Geophys. Res.-Atmos., 113, D14212, https://doi.org/10.1029/2007jd009752, 2008.

Renard, J.-B., Dulac, F., Durand, P., Bourgeois, Q., Denjean, C., Vignelles, D., Couté, B., Jeannot, M., Verdier, N., and Mallet, M.: In situ measurements of desert dust particles above the western Mediterranean Sea with the balloon-borne Light Optical Aerosol Counter/sizer (LOAC) during the ChArMEx campaign of summer 2013, Atmos. Chem. Phys., 18, 3677-3699, https://doi.org/10.5194/acp-18-3677-2018, 2018.

Rocha-Lima, A., Martins, J. V., Remer, L. A., Todd, M., Marsham, J. H., Engelstaedter, S., Ryder, C. L., Cavazos-Guerra, C., Artaxo, P., Colarco, P., and Washington, R.: A detailed characterization of the Saharan dust collected during the Fennec campaign in 2011: in situ ground-based and laboratory measurements, Atmos. Chem. Phys., 18, 1023-1043, https://doi.org/10.5194/acp18-1023-2018, 2018.

Ryder, C. L., Highwood, E. J., Lai, T. M., Sodemann, H., and Marsham, J. H.: Impact of atmospheric transport on the evolution of microphysical and optical properties of Saharan dust, Geophys. 
Res. Lett., 40, 2433-2438, https://doi.org/10.1002/Grl.50482, 2013a.

Ryder, C. L., Highwood, E. J., Rosenberg, P. D., Trembath, J., Brooke, J. K., Bart, M., Dean, A., Crosier, J., Dorsey, J., Brindley, H., Banks, J., Marsham, J. H., McQuaid, J. B., Sodemann, H., and Washington, R.: Optical properties of Saharan dust aerosol and contribution from the coarse mode as measured during the Fennec 2011 aircraft campaign, Atmos. Chem. Phys., 13, 303325, https://doi.org/10.5194/acp-13-303-2013, 2013 b.

Ryder, C. L., McQuaid, J. B., Flamant, C., Rosenberg, P. D., Washington, R., Brindley, H. E., Highwood, E. J., Marsham, J. H., Parker, D. J., Todd, M. C., Banks, J. R., Brooke, J. K., Engelstaedter, S., Estelles, V., Formenti, P., Garcia-Carreras, L., Kocha, C., Marenco, F., Sodemann, H., Allen, C. J. T., Bourdon, A., Bart, M., Cavazos-Guerra, C., Chevaillier, S., Crosier, J., Darbyshire, E., Dean, A. R., Dorsey, J. R., Kent, J., O’Sullivan, D., Schepanski, K., Szpek, K., Trembath, J., and Woolley, A.: Advances in understanding mineral dust and boundary layer processes over the Sahara from Fennec aircraft observations, Atmos. Chem. Phys., 15, 8479-8520, https://doi.org/10.5194/acp15-8479-2015, 2015.

Ryder, C. L., Marenco, F., Brooke, J. K., Estelles, V., Cotton, R., Formenti, P., McQuaid, J. B., Price, H. C., Liu, D., Ausset, P., Rosenberg, P. D., Taylor, J. W., Choularton, T., Bower, K., Coe, H., Gallagher, M., Crosier, J., Lloyd, G., Highwood, E. J., and Murray, B. J.: Coarse-mode mineral dust size distributions, composition and optical properties from AER-D aircraft measurements over the tropical eastern Atlantic, Atmos. Chem. Phys., 18, 17225-17257, https://doi.org/10.5194/acp-18-172252018, 2018.

Samset, B. H., Stjern, C. W., Andrews, E., Kahn, R. A., Myhre, G., Schulz, M., and Schuster, G. L.: Aerosol Absorption: Progress Towards Global and Regional Constraints, Curr. Clim. Change Rep., 4, 65-83, https://doi.org/10.1007/s40641-0180091-4, 2018.

Saxby, J., Beckett, F., Cashman, K., Rust, A., and Tennant, E.: The impact of particle shape on fall velocity: Implications for volcanic ash dispersion modelling, J. Volcanol. Geoth. Res., 362, 32-48, https://doi.org/10.1016/j.jvolgeores.2018.08.006, 2018.

Seibert, P. and Frank, A.: Source-receptor matrix calculation with a Lagrangian particle dispersion model in backward mode, Atmos. Chem. Phys., 4, 51-63, https://doi.org/10.5194/acp-4-512004, 2004.

Seinfeld, J. H. and Pandis, S. N.: Properties of the Atmospheric Aerosol, in: Atmospheric Chemistry and Physics: From Air Pollution to Climate Change, 2 Edn., John Wiley \& Sons, New Jersey, USA, 350-388, 2006.

Shettle, E. P. and Fenn, R. W.: Models for the Aerosols of the Lower Atmosphere and the Effects of Humidity Variations on Their Optical Properties, Air Force Geophysics Laboratory Environmental Research Papers, Hanscomb, MA, 25 pp., 1979.

Sicard, M., Bertolín, S., Mallet, M., Dubuisson, P., and Comerón, A.: Estimation of mineral dust long-wave radiative forcing: sensitivity study to particle properties and application to real cases in the region of Barcelona, Atmos. Chem. Phys., 14, 9213-9231, https://doi.org/10.5194/acp-14-9213-2014, 2014.

Smith, M.: Facility for Airborne Atmospheric Measurements; Met Office, Natural Environment Research Council, Facility for Airborne Atmospheric Measurements (FAAM) flights, NCAS
British Atmospheric Data Centre, available at: https://catalogue. ceda.ac.uk/uuid/affe775e8d8890a4556aec5bc4e0b45c, last access: 2 December 2019, 2004.

Solmon, F., Elguindi, N., and Mallet, M.: Radiative and climatic effects of dust over West Africa, as simulated by a regional climate model, Clim. Res., 52, 97-113, https://doi.org/10.3354/cr01039, 2012.

Stevenson, J. A., Millington, S. C., Beckett, F. M., Swindles, G. T., and Thordarson, T.: Big grains go far: understanding the discrepancy between tephrochronology and satellite infrared measurements of volcanic ash, Atmos. Meas. Tech., 8, 2069-2091, https://doi.org/10.5194/amt-8-2069-2015, 2015.

Stohl, A., Hittenberger, M., and Wotawa, G.: Validation of the Lagrangian particle dispersion model FLEXPART against largescale tracer experiment data, Atmos. Environ., 32, 4245-4264, https://doi.org/10.1016/S1352-2310(98)00184-8, 1998.

Stohl, A., Forster, C., Frank, A., Seibert, P., and Wotawa, G.: Technical note: The Lagrangian particle dispersion model FLEXPART version 6.2, Atmos. Chem. Phys., 5, 2461-2474, https://doi.org/10.5194/acp-5-2461-2005, 2005.

Strong, J. D. O., Vecchi, G. A., and Ginoux, P.: The Climatological Effect of Saharan Dust on Global Tropical Cyclones in a Fully Coupled GCM, J. Geophys. Res.-Atmos., 123, 5538-5559, https://doi.org/10.1029/2017jd027808, 2018.

Tegen, I. and Lacis, A. A.: Modeling of particle size distribution and its influence on the radiative properties of mineral dust aerosol, J. Geophys. Res.-Atmos., 101, 19237-19244, https://doi.org/10.1029/95jd03610, 1996.

Toth III, J. R., Rajupet, S., Squire, H., Volbers, B., Zhou, J., Xie, L., Sankaran, R. M., and Lacks, D. J.: Electrostatic forces alter particle size distributions in atmospheric dust, Atmos. Chem. Phys. Discuss., https://doi.org/10.5194/acp-2019-650, in review, 2019.

Tsamalis, C., Chédin, A., Pelon, J., and Capelle, V.: The seasonal vertical distribution of the Saharan Air Layer and its modulation by the wind, Atmos. Chem. Phys., 13, 11235-11257, https://doi.org/10.5194/acp-13-11235-2013, 2013.

van der Does, M., Korte, L. F., Munday, C. I., Brummer, G.-J. A., and Stuut, J.-B. W.: Particle size traces modern Saharan dust transport and deposition across the equatorial North Atlantic, Atmos. Chem. Phys., 16, 13697-13710, https://doi.org/10.5194/acp-16-13697-2016, 2016.

van der Does, M., Knippertz, P., Zschenderlein, P., Harrison, R. G., and Stuut, J. B. W.: The mysterious long-range transport of giant mineral dust particles, Sci. Adv., 4, eaau2768, https://doi.org/10.1126/sciadv.aau2768, 2018.

Volz, F. E.: Infrared Optical-Constants of Ammonium Sulfate, Sahara Dust, Volcanic Pumice, and Flyash, Appl. Opt., 12, 564568, https://doi.org/10.1364/Ao.12.000564, 1973.

Walser, A., Sauer, D., Spanu, A., Gasteiger, J., and Weinzierl, B.: On the parametrization of optical particle counter response including instrument-induced broadening of size spectra and a self-consistent evaluation of calibration measurements, Atmos. Meas. Tech., 10, 4341-4361, https://doi.org/10.5194/amt10-4341-2017, 2017.

Washington, R., Flamant, C., Parker, D. J., Marsham, J. H., McQuaid, J. B., Brindley, H., Todd, M., Highwood, E. J., Ryder, C. L., Chaboureau, J.-P., Kocha, C., Bechir, M., and Saci, A. Fennec - The Saharan Climate System, CLIVAR Exchanges, 17, 31-32, 2012. 
Weinzierl, B., Petzold, A., Esselborn, M., Wirth, M., Rasp, K., Kandler, K., Schütz, L., Koepke, P., and Fiebig, M.: Airborne measurements of dust layer properties, particle size distribution and mixing state of Saharan dust during SAMUM 2006, Tellus B, 61, 96-117, https://doi.org/10.1111/j.1600-0889.2008.00392.x, 2009.

Weinzierl, B., Sauer, D., Esselborn, M., Petzold, A., Veira, A., Rose, M., Mund, S., Wirth, M., Ansmann, A., Tesche, M., Gross, S., and Freudenthaler, V.: Microphysical and optical properties of dust and tropical biomass burning aerosol layers in the Cape Verde region-an overview of the airborne in situ and lidar measurements during SAMUM-2, Tellus B, 63, 589-618, https://doi.org/10.1111/j.1600-0889.2011.00566.x, 2011.

Weinzierl, B., Sauer, D., Minikin, A., Reitebuch, O., Dahlkotter, F., Mayer, B., Emde, C., Tegen, I., Gasteiger, J., Petzold, A., Veira, A., Kueppers, U., and Schumann, U.: On the visibility of airborne volcanic ash and mineral dust from the pilot's perspective in flight, Phys. Chem. Earth, 45, 87-102, https://doi.org/10.1016/j.pce.2012.04.003, 2012.

Weinzierl, B., Ansmann, A., Prospero, J. M., Althausen, D., Benker, N., Chouza, F., Dollner, M., Farrell, D., Fomba, W. K., Freudenthaler, V., Gasteiger, J., Gross, S., Haarig, M., Heinold, B., Kandler, K., Kristensen, T. B., Mayol-Bracero, O. L., Muller, T., Reitebuch, O., Sauer, D., Schafler, A., Schepanski, K., Spanu, A., Tegen, I., Toledano, C., and Walser, A.: The Saharan Aerosol Long-range Transport and Aerosol-cloud-interaction experiment: Overview and Selected Highlights, B. Am. Meteorol. Soc., 98, 1427-1451, https://doi.org/10.1175/Bams-D-15$00142.1,2017$.
Whitby, K. T.: Physical Characteristics of Sulfur Aerosols, Atmos. Environ., 12, 135-159, https://doi.org/10.1016/00046981(78)90196-8, 1978.

WMO: World Meteorological Organization Report of the Experts Meeting on Aerosols and Their Climatic Effects, Geneva, Switzerland, 1983.

Woodage, M. J. and Woodward, S.: UK HiGEM: Impacts of Desert Dust Radiative Forcing in a High-Resolution Atmospheric GCM, J. Climate, 27, 5907-5928, https://doi.org/10.1175/Jcli-D-13$00556.1,2014$.

Woodward, S.: Modeling the atmospheric life cycle and radiative impact of mineral dust in the Hadley Centre climate model, J. Geophys. Res.-Atmos., 106, 18155-18166, https://doi.org/10.1029/2000jd900795, 2001.

Yang, P., Feng, Q., Hong, G., Kattawar, G. W., Wiscombe, W. J., Mishchenko, M. I., Dubovik, O., Laszlo, I., and Sokolik, I. N.: Modeling of the scattering and radiative properties of nonspherical dust-like aerosols, J. Aerosol. Sci., 38, 995-1014, https://doi.org/10.1016/j.jacrosci.2007.07.001, 2007.

Yu, H. B., Chin, M., Yuan, T. L., Bian, H. S., Remer, L. A., Prospero, J. M., Omar, A., Winker, D., Yang, Y. K., Zhang, Y., Zhang, Z. B., and Zhao, C.: The fertilizing role of African dust in the Amazon rainforest: A first multiyear assessment based on data from Cloud-Aerosol Lidar and Infrared Pathfinder Satellite Observations, Geophys. Res. Lett., 42, 1984-1991, https://doi.org/10.1002/2015gl063040, 2015. 